\author{
ARIEL ORZEEEK \\ https://orcid.org/0000-0001-5360-464X \\ UMCS w Lublinie
}

\title{
U GENEZY CHRZEŚCIJAŃSKIEGO STOWARZYSZENIA SPOEECZNEGO. POWSTANIE I ROZPAD PIERWSZEGO ZESPOŁU REDAKCYJNEGO TYGODNIKA „ZA I PRZECIW”*
}

\begin{abstract}
Abstrakt: Jesienią 1956 r. Stowarzyszenie „Pax”, najpotężniejsza organizacja polityczna katolików świeckich w PRL, przeżyło rozłam. Grupa działaczy z Janem Frankowskim i Konstantym Łubieńskim na czele dążyła do usunięcia $\mathrm{z}$ jego kierownictwa Bolesława Piaseckiego, a gdy okazało się to niemożliwe, do utworzenia nowej organizacji. Dyskusja nad jej obliczem ideowym na łamach nowo powstałego tygodnika ,Za i Przeciw" doprowadziła do konfliktu między Frankowskim i jego współpracownikami oraz powołania Chrześcijańskiego Stowarzyszenia Społecznego.
\end{abstract}

Słowa kluczowe: Chrześcijańskie Stowarzyszenie Społeczne, odwilż 1956, Stowarzyszenie „Pax”, tygodnik „Za i Przeciw”, Kościół katolicki, Jan Frankowski.
Abstract: In the autumn of 1956, the PAX Association, the most powerful political organisation of the secular Catholics in the Polish People's Republic, experienced a split. A group of activists, with Jan Frankowski and Konstanty Łubieński at the head, wanted to remove Bolesław Piasecki from the Association's leadership, and when this became impossible, to establish a new organisation. A discussion on its ideological shape in the weekly Za i Przeciw (For and Against) led to a conflict between Frankowski and his colleagues and ultimately to the formation of the Christian Social Association (Chrześcijańskie Stowarzyszenie Społeczne).

Keywords: Christian Social Association, 1956 Thaw, PAX Association, Za i Przeciw weekly, Catholic Church, Jan Frankowski.

* Powstanie artykułu było możliwe dzięki dofinansowaniu z Narodowego Centrum Nauki w ramach konkursu „Miniatura 2” (projekt: „O wielości dróg katolików świeckich w Polsce Ludowej. Koncepcje polityczne Jerzego Hagmajera, Jana Frankowskiego i Konstantego Łubieńskiego - kwerenda wstępna”, nr 2018/02/X/HS3/02761). 
Powołane w 1957 r. Chrześcijańskie Stowarzyszenie Społeczne (ChSS), powstałe na skutek mającej miejsce rok wcześniej secesji w Stowarzyszeniu „Pax”, jest najsłabiej poznanym ugrupowaniem katolików świeckich w Polsce Ludowej ${ }^{1}$. Wynika to głównie z faktu, że nie było ono zbyt aktywne politycznie i nie rościło sobie pretensji do snucia oryginalnych koncepcji ideowych. W dużej mierze było to konsekwencją wydarzeń, jakie zaszły w grupie tygodnika „Za i Przeciw” od marca do października 1957 r. Wówczas to na łamach tego pisma toczyła się dyskusja ideowa z udziałem przede wszystkim Andrzeja Micewskiego, Konstantego Łubieńskiego, Wojciecha Kętrzyńskiego i Dominika Horodyńskiego, której nurt zmierzał wyraźnie w kierunku syntezy koncepcji radykalnie lewicowych z bardzo ogólnie pojmowaną inspiracją chrystianizmem ${ }^{2}$. Oznaczało to odejście tak od paksowskiej wieloświatopoglądowości $i^{3}$, jak też od neopozytywizmu Znaku ${ }^{4}$. Wywołało to kontrakcję naczelnego „Za i Przeciw”, Jana Frankowskiego, który doprowadził do usunięcia z zespołu redakcyjnego czołowych „lewicowców” i niedawnych „secesjonistów”, w czym miał poparcie innego działacza tego środowiska, Aleksandra Bocheńskiego. Celem niniejszego tekstu jest omówienie tego procesu, mającego niebagatelne znaczenie dla środowisk katolików świeckich w PRL, sankcjonującego podział na wyraziste Pax i Znak oraz bezbarwne ChSS. Jak się okaże, wydarzenia te miały też związek z „odchodzeniem od Października" przez kierownictwo partyjne i państwowe.

${ }^{1}$ Najpełniej genezę ChSS zarysował dotychczas Andrzej Friszke (Nadzieje i złudzenia. Środowiska katolików świeckich przed i po Październiku 1956, w: Sensus catholicus. Katolicy świeccy $w$ Polsce Ludowej. Postawy - aktywność - myśl. Studia i szkice, red. R. Ptaszyński, T. Sikorski, Torun 2014, s. 100-106). Pewne mniej ogólnikowe informacje o stowarzyszeniu zawiera jedynie starsze już opracowanie Haliny Lisickiej (Pluralizm światopogladowy w koncepcjach Pax, ChSS, PZKS, Wrocław 1991) oraz artykuły: D. Gucewicz, Dywersyjna rola Chrześcijańskiego Stowarzyszenia Społecznego w ruchu katolickim (na przykładzie Gdańska), w: Sensus catholicus, s. 627-646; T. Błaszak, Służba Bezpieczeństwa wobec Stowarzyszenia Pax i Chrześcijańskiego Stowarzyszenia Społecznego w województwie szczecińskim w latach 19521990, w: ibidem, s. 647-655.

${ }^{2}$ Co było odległe od „katolickiego socjalizmu” ruchu Bolesława Piaseckiego, świetnie zanalizowanego przez Piotra H. Kosickiego (Personalizm po polsku. Francuskie korzenie polskiej inteligencji katolickiej, Warszawa 2016, s. 285-395).

3 B. Bankowicz, W labiryncie wieloświatopogladowości. Stowarzyszenie Pax między realizmem a rzeczywistościa, w: B. Bankowicz, A. Dudek, Ze studiów nad dziejami Kościoła i katolicyzmu $w$ PRL, Kraków 1996, s. 53-71; eadem, Stowarzyszenie Pax. Między rzeczywistościa socjalizmu realnego a utopia socjalizmu wieloświatopoglądowego, w: Doktryny. Historia. Władza. Księga dedykowana profesorowi Wiesławowi Kozubowi-Cembroniewiczowi z okazji czterdziestolecia pracy naukowej, red. A. Citkowska-Kimla, M. Kiwior-Filo, B. Szlachta, Kraków 2009, s. 37-48.

${ }^{4}$ B. Bankowicz, Neopozytywizm Znaku. Próba legalizmu motywowana realizmem, w: B. Bankowicz, A. Dudek, op. cit., s. 37-52. 


\section{Główni bohaterowie}

Na początku warto przyjrzeć się działalności liderów „secesji” w okresie do 1956 r. Może być to pomocne w zrozumieniu ich politycznych wyborów i poglądów w latach 1956-1957.

Jan Frankowski, urodzony w 1912 r., pochodził z Kielecczyzny. Wykształcenie prawnicze i ekonomiczne zdobył w Poznaniu, angażując się w pracę jednostek samorządowych i gospodarczych. Równocześnie pasjonowała go katolicka myśl społeczna. Związany ze Stowarzyszeniem Katolickiej Młodzieży Akademickiej „Odrodzenie”, a następnie z ruchem „mocarstwowym” II RP, publikował liczne artykuły, w których starał się dokonywać syntezy ówczesnego „katolicyzmu postępowego” i koncepcji lewicowych, inspirując się Kazimierzem Sołtysikiem i Henrykiem Dembińskim. Deklarując się jako antykomunista i obrońca własności prywatnej, równocześnie uznawał utylitarne znaczenie tej zasady. Postulowany przez niego model katolicyzmu pozwala zaliczyć go do grona prekursorów myśli odnowicielskiej w Kościele. W latach wojny powrócił w rodzinne strony, angażując się jednocześnie w działalność katolickiej „Unii”. Po 1944 r. podjął pracę w administracji państwowej, zbliżając się stopniowo do środowiska Piaseckiego, krótko wiążąc się ze Stronnictwem Pracy Karola Popiela. W 1947 r. został posłem na Sejm Ustawodawczy z ramienia Klubu Katolicko-Społecznego. Zdaniem jego kolegi z ław poselskich, Bocheńskiego, miał być liderem frakcji wyrażającej tendencje opozycyjne wobec dawnego wodza Falangi. W 1953 r. jego akces do zespołu kierowniczego Paxu został zablokowany przez Tadeusza Mazowieckiego, Janusza Zabłockiego i Leonarda Barszczewskiego, członkiem tego gremium został wobec tego rok później. Z czasem stał się jednym z liderów grupy, w dalszym ciągu zasiadając w parlamencie. Rok 1956 zastał go jako jednego z ekspertów Stowarzyszenia od spraw gospodarczych oraz prawnych ${ }^{5}$.

${ }^{5}$ AAN, Urząd Rady Ministrów w Warszawie, sygn. 16/279, Karta personalna Jana Frankowskiego, Lublin, 22 I 1945 r., b.pag.; ibidem, Życiorys Jana Frankowskiego, Lublin, 9 I 1945 r., b.pag.; AIPN, 00231/231/1 [sprawa operacyjnego rozpracowania Jana Frankowskiego], Arkusz informacyjny dot. Jana Frankowskiego, k. 14; ibidem, 00231/231/2 [sprawa operacyjnego rozpracowania Jana Frankowskiego], „Wyciąg z informacji tw. «D»", 20 VII 1967, k. 10; Archiwum Państwowe w Lublinie, Archiwum Łosiów z Niemiec, 123, List Aleksandra Bocheńskiego do Jana Stanisława Łosia, 1947 r., k. 176-177; J. Frankowski, Katolicyzm w Polsce współczesnej. Artykuł dyskusyjny, „Bunt Młodych” 1934, 7, s. 5; idem, Akcja katolicka. Artykuł dyskusyjny, „Bunt Młodych” 1935, 12-13, s. 6; idem, Sprawiedliwość i miłosierdzie a kwestja społeczna, „Pax” 1934, 4, s. 1-2; idem, Odszedł apostoł jutra (O ś. p. Kazimierzu Sołtysiku), „Polityka” 1938, 3, s. 5-6; idem, Sokrates mojej młodości, „Słowo Powszechne” (dalej: SP) 1955, 85, s. 9-10; idem, Budżet i plan na rok 1951, „Życie 
Konstanty Łubieński, który, według Stefana Kisielewskiego, szedł do Paxu „krętymi drogami”, urodził się w 1910 r. w rodzinie arystokratycznej, dziedzicząc tytuł hrabiowski. W okresie II Rzeczypospolitej, jak sam wspominał, „postępowe” były jedynie jego poglądy w kwestii mniejszościowej. W tym czasie pozostawał pod przemożnym wpływem ideowym Ksawerego Pruszyńskiego. Z wykształcenia, podobnie jak Frankowski, prawnik, a z zamiłowania ekonomista, w czasie wojny działał w Armii Krajowej, będąc komendantem Inspektoratu AK Mielec. Po 1945 r. podjął pracę w administracji państwowej, stopniowo zbliżając się do grupy Piaseckiego. W 1948 r. ogłosił na łamach „Dziś i Jutro” głośny artykuł List otwarty do pana Juliusza Łady, będący czytelnym sygnałem przejścia „ruchu nienazwanego" na pozycje afirmacji nie tylko geopolitycznych, ale i ustrojowo-ekonomicznych realiów Polski Ludowej. Rok 1956 zastał go nie tylko jako jednego z liderów i ideologów Paxu, ale także „człowieka do specjalnych poruczeń" 6 .

Wojciech Kętrzyński był w tym gronie najbliższy osobiście Piaseckiemu, będąc jego adiutantem w latach wojny. Urodzony w roku 1918, w II Rzeczypospolitej nie zdążył podjąć działalności politycznej. Z Konfederacji Narodu (KN) i jej Uderzeniowych Batalionów Kadrowych wiodła go dość prosta droga do grupy „Dziś i Jutro” (u schyłku wojny pozostawał w orbicie ideowych wpływów Bocheńskiego, w batalionach natomiast należał do najbliższych współpracowników Piaseckiego). Do 1956 r. był jednym z najważniejszych publicystów prasowych ruchu. Jeszcze w roku przemian październikowych zamieszczał artykuły programowe wpisujące się w linię polityczną Paxu, a nawet bronił lidera Stowarzyszenia przed

i Myśl" (dalej: ŻiM) 1951, 5-6, s. 566-579; Z życia Stronnictwa Pracy. Zjazd gospodarczy Stronnictwa Pracy, „Odnowa” 1946, 4, s. 3; J. Zabłocki, Dzienniki 1956-1965, t. 1, Warszawa 2008, s. 72; A.W. Kaczorowski, Frankowski Jan Józef, w: Słownik biograficzny katolicyzmu społecznego w Polsce. A-J, red. R. Bender et al., Lublin 1994, s. 134; W. Bujak, Historia Stronnictwa Pracy 1937-1946-1950, Warszawa 1988, s. 142-143.

${ }^{6}$ AIPN, 0648/137 [Klub Inteligencji Katolickiej - materiały dot. Konstantego Łubieńskiego], „Arkusz rejestracyjny rozpracowywanego w sprawie zagadnieniowej nr 446 kryptonim «Zacisze» o zabarwieniu klerykalnym", k. 6; ibidem, Odpis listu Bolesława Piaseckiego do Konstantego Łubieńskiego, 6 XI 1955, k. 19-20; ibidem, 0648/138 [sprawa operacyjnego rozpracowania Konstantego Łubieńskiego], „Informacja dot. działalności K. Łubieńskiego w USA, Anglii i Francji (wrzesień-grudzień 1955)”, 11 III 1963, k. 54-56; K. Łubieński, Kartki z wojny, Warszawa 1976, passim; idem, List otwarty do Pana Juliusza Eady (Na marginesie notatki w „The Tablet”), „Dziś i Jutro” (dalej: DiJ) 1948, 49, s. 1-2; idem, Człowiek polityki i sztuki (Fragmenty wspomnień o ś.p. Ksawerym Pruszyńskim), DiJ 1951, 26, s. 3; idem, Uprzemysłowienie Polski podstawa Frontu Narodowego, Dij 1952, 40, s. 4; idem, Na starcie. Wspomnienia z lat 1948-1950, „Przegląd Socjologiczny” 1971, 24, s. 381-396; S. Kisielewski, Abecadło Kisiela, Warszawa 1990, s. 62. 
krytyką. Jednak już u schyłku grudnia 1956 r. wyrażał dość popularne wśród polskich katolików nadzieje, że zwycięstwo Piaseckiego w walce o władzę w organizacji było tylko chwilowe - kompromitacja i izolacja Stowarzyszenia musiały doprowadzić do przejęcia go przez „reformatorów” (czyli secesję), co miało pozwolić zachować jego wieloletni, pozytywny dorobek. Według nieżyczliwej Kętrzyńskiemu opinii informatora o pseudonimie „Kowalski”, miał się on cechować wyjątkową przebiegłością polityczną i ambicją, której podporządkowywał metody swego działania. Nie zważając zatem na swą znajomość z przywódcą Paxu, dzięki zakulisowej grze usiłował zająć jego miejsce już u schyłku lat czterdziestych $^{7}$ (według innej informacji o przywództwo konkurował z nim już w Konfederacji Narodu) ${ }^{8}$.

Niemalże rówieśnikiem Kętrzyńskiego był urodzony w 1919 r. Dominik Horodyński. W latach wojny związany z KN i AK (w Uderzeniowych Batalionach Kadrowych był jednym z najważniejszych pracowników sztabu i również, według niejasnych informacji, konkurował z Piaseckim o przywództwo), walczył w powstaniu warszawskim. Podobnie jak na Kętrzyńskiego silnie oddziaływał na niego Bocheński, który niejako „zaopiekował się" nim ideowo po śmierci jego rodziny w masakrze w Zbydniowie w 1943 r. Horodyński był jednym z głównych inicjatorów koncepcji porozumienia katolickich środowisk intelektualnych z komunistami, na co częściowy wpływ mogły mieć jego traumatyczne doświadczenia. W 1952 r. został posłem, a już od zarania ruchu katolików „społecznie postępowych” był jednym z jego najważniejszych publicystów i ideologów. Miał przy tym opinię działacza niezwykle ambitnego, otwarcie konkurującego z Piaseckim o pozycję lidera9 .

${ }^{7}$ AIPN, 0648/169/2 [sprawa operacyjnego rozpracowania ChSS], „Doniesienie informacyjne. Przyczynek do wstępnej charakterystyki Wojciecha Kętrzyńskiego” [źródło: „Kowalski”], 18 VI 1957, k. 62-63; AAN, Spółka Wydawnicza Pax w Warszawie. Wydział Ideologiczny, 203, W. Kętrzyński, „Ruch personalistyczny”, k. 1-8; W. Kętrzyński, Na przełomie 1944-1945, „Więź” 1967, 11-12, s. 160-171; idem, Warszawa 1944, „Tygodnik Powszechny" (dalej: TP) 1945, 21, s. 1; idem, Skąd i dokąd idziemy, DiJ 1950, 47, s. 3-4; idem, Rozważania o stosunku rewolucji socjalistycznej do światopoglądu religijnego, ŻiM 1956, 3, s. 49-67; idem, List do redakcji, SP 1956, 256, s. 1; idem, I co dalej z Pax-em, ŻiM 1957, 1, s. 202-203; P. Kardela, W służbie bezpieki i narodu. Wojciech Kętrzyński (1918-1983), „Rocznik Mazurski” 19, 2015, s. 151-180; K. Krajewski, Uderzeniowe Bataliony Kadrowe 1942-1944, Warszawa 1993, passim.

${ }^{8}$ AIPN, 0648/48/1 [materiały dot. działalności Stowarzyszenia „Pax”], „Meldunek nr 222/63 [źródło: „Adam Piotrowski”], k. 4.

9 Ibidem, k. 4-6; D. Horodyński, $W$ tragiczna rocznicę, Dij 1946, 30, s. 2; idem, 22 lipca, SP 1950, 198, s. 1; idem, Sens tego sojuszu, SP 1951, 270, s. 1; A. Friszke, Dominika Horodyńskiego „uzupetnienia” historyczne, „Więź” 2001, 10, s. 120-135; idem, Między wojna 
Najmłodszy w tym gronie (urodzony w 1926 r.) Andrzej Micewski, z wykształcenia prawnik, w powojenną politykę wkroczył z AK-owską przeszłością. Pokładając w Piaseckim duże nadzieje, początkowo był jednak zaangażowany w zespół „Tygodnika Warszawskiego”. Przełożyło się to na jego pracę w Komisji Intelektualistów i Działaczy Katolickich przy Polskim Komitecie Obrońców Pokoju, w zarządzie upaństwowionego Caritasu czy w redakcji przejętego „Tygodnika Powszechnego”, ale też na publicystykę, w której przez wiele lat w pełni aprobował polityczną taktykę Piaseckiego ${ }^{10}$.

Urodzony w 1904 r. Aleksander Bocheński był, podobnie jak Frankowski, jednym z czołowych ideologów grupy Jerzego Giedroycia. Był ekspertem zwłaszcza od problematyki mniejszości narodowych i polityki zagranicznej. Opierając się na swoiście rozumianym politycznym realizmie, podczas II wojny światowej snuł koncepcje porozumienia z Niemcami, a u jej schyłku z Sowietami, kładąc podwaliny pod grupe „Dziś i Jutro”. Jego głośne Dzieje głupoty w Polsce uznano w otoczeniu Piaseckiego za zbyt krytyczne wobec tradycji insurekcyjnej. Sam Bocheński z dużą rezerwą odnosił się do działalności Paxu. W 1953 r. w zasadzie zaniechał działalności politycznej i publicystycznej. Dopiero powołanie periodyku „Kierunki” w maju 1956 r. skłoniło go do powrotu do pracy pisarskiej. Chociaż uchodził wówczas, na skutek swych towarzyskich związków z Paxem, za działacza bliskiego Piaseckiemu politycznie (lecz niepodzielającego w pełni jego poglądów), z pewnością nie zaliczano go do grona prominentów Stowarzyszenia (członkiem Paxu został dopiero w 1962 r.). Jak się miało okazać, mimo perspektyw na to, nie zdecydował się zostać jednym z liderów „Za i Przeciw”11.

a więzieniem 1945-1953. Młoda inteligencja katolicka, Warszawa 2015, s. 56-59, 73-79; K. Krajewski, op. cit., s. 107-108, 118, 159, 202.

${ }^{10}$ ANK, Wojewódzki Komitet Frontu Jedności Narodu w Krakowie, 7, „Protokół narady Duchownych i Świeckich Działaczy Katolickich Frontu Narodowego”, 11 III 1954, k. 81-83; A. Micewski, O stosunkach polsko-radzieckich, SP 1951, 279, s. 3; idem, Wieloświatopoglądowość, SP 1956, 4, s. 3; idem, Nienaruszalność zasad pryncypialnych, SP 1956, 139, s. 4; A. Friszke, Między wojna, s. 103-110.

11 Archiwum Katolickiego Stowarzyszenia Civitas Christiana w Warszawie, teczka Aleksandra Bocheńskiego, VII A-305, „Jak doszło do powstania «Dziś i Jutro». Dyskusja na łamach «Życia i Myśli»" [nieopublikowana], 1975, k. 1-27; ibidem, b.sygn., Podanie Aleksandra Bocheńskiego do Zarządu Stowarzyszenia „Pax” w sprawie przyjęcia w poczet członków Stowarzyszenia, 8 II 1962, b.pag.; A. Bocheński, Dzieje głupoty w Polsce. Pamflety dziejopisarskie, Warszawa 1947, passim; idem, Jeszcze o instynkcie narodowym i Panu J. E. Skiwskim, „Polityka” 1938, 14, s. 6; R. Mozgol, Ryzykowna gra. Jak Aleksander Bocheński przyczynit się do powstania „Dziś i Jutro”, „Biuletyn Instytutu Pamięci Narodowej” 2007, 4, s. 84-92. 


\section{Kryzys w Stowarzyszeniu "Pax” w 1956 roku i "secesja”}

Stowarzyszenie „Pax” było w latach 1953-1956 jedynym legalnym ośrodkiem działalności politycznej i publicystycznej katolików świeckich w Polsce Ludowej. Rozbicie „Tygodnika Warszawskiego"12 w 1948 r. i wcześniejsza wasalizacja Stronnictwa Pracy ${ }^{13}$ zniszczyły nurty chadecki i narodowo-chrześcijański, przejęcie zaś „Tygodnika Powszechnego" przez grupę Piaseckiego w 1953 r. usunęło z życia publicznego środowisko obywatelsko-personalistyczne, prowadzące poważną debatę nad granicami zaangażowania katolików w nowym systemie. Wprowadzone przez 1946 r. Stanisława Stommę pojęcia „minimalizmu” i „maksymalizmu" wyznaczały oś sporu, w który potem, nie zawsze zresztą świadomie, wpisywali się bohaterowie niniejszego tekstu, na czele z Frankowskim. Stomma maksymalizmem nazywał próbę syntezy katolicyzmu z ambicjami narodowymi i dogmatyczne traktowanie katolickiej nauki społecznej, dające efekt w postaci odrzucenia jakiejkolwiek możliwości ugody z komunistami. Minimalizmem była w jego optyce postawa indywidualistyczna i bardziej pragmatyczna, oparta o konsekwencje wywiedzione z realistycznej oceny sytuacji sprawy polskiej. Zgodzić się można z Piotrem H. Kosickim, że całą sprawę publicysta rozpatrywał w kontekście stosunku polskich wierzących do francuskiej myśli katolickiej (oczywiście w kontekście powojennych uwarunkowań). Zdaniem dość życzliwych analityków koncepcja Stommy oznaczała kapitulację wobec politycznych zamierzeń komunistów i dążenie do obrony jedynie kluczowych imponderabiliów katolickich. Krytycy nieżyczliwi zarzucali mu skrajny oportunizm. Nie można jednak zapominać, że Stomma w odpowiedzi na głosy krytyki podkreślał, iż minimalizm jest jedynie sposobem na przetrwanie katolicyzmu w niekorzystnych warunkach, w artykułach pisanych wspólnie z Jerzym Turowiczem zaznaczał on zasadniczą rozbieżność marksizmu i chrystianizmu, swoją postawą zaś w latach pięćdziesiątych zarówno on, jak i „Tygodnik Powszechny" dowiedli, że dostrzegają granicę kompromisu ${ }^{14}$.

12 T. Sikorski, M. Kulesza, Niezłomni w epoce fałszywych proroków. Środowisko „Tygodnika Warszawskiego" (1945-1948), Warszawa 2013, s. 112-115.

${ }^{13}$ M. Piotrowski, Stużba idei czy serwilizm? Zygmunt Felczak i Feliks Widy-Wirski w najnowszych dziejach Polski, Lublin 1994, s. 193-278; W. Bujak, op. cit., s. 117-191; A. Andrusiewicz, Stronnictwo Pracy 1937-1950. Ze studiów nad dziejami najnowszymi chadecji w Polsce, Warszawa 1988, s. 200-243.

14 S. Stomma, Maksymalne i minimalne tendencje społeczne katolików, „Znak” 1946, 3, s. 257-275; idem, o pozornym maksymalizmie i urojonym defetyzmie, TP 1947, 16, s. 5; 
Czym innym jest „minimalizm”, czy też, mówiąc inaczej, polityczny realizm, a czym innym oportunizm.

$\mathrm{Na}$ marginesie warto zadać pytanie, kim był w takim kontekście Piasecki - minimalistą, maksymalistą, oportunistą, marzycielem czy realistą? Wszak chcąc bronić uprawnień Kościoła, szedł bardzo daleko w swoim ideologicznym i praktycznym poparciu dla władz z jednej strony, z drugiej zaś snuł ambitne polityczne plany „przezwyciężenia zwycięzcy". Jest to tym bardziej istotne, że sam ruch skupiony od $1945 \mathrm{r}$. wokół „Dziś i Jutro” (od 1947 r. dodatkowo wokół „Słowa Powszechnego") nie był jednolity ideowo. Gromadził on początkowo ludzi o przekonaniach narodowo-katolickich oraz konserwatywno-realistycznych ${ }^{15}$, stopniowo ewoluując w kierunku aprobaty nie tylko geopolitycznych, ale też ustrojowo-ekonomicznych realiów powojennej Polski. Stosunkowo znaczny pluralizm na łamach prasy tzw. ruchu nienazwanego uległ w miarę upływu czasu ukróceniu, niemniej ciągle byli na jej szpaltach reprezentowani działacze o rozmaitej proweniencji ideowej i politycznej. Wyróżnić można spośród nich: 1) grupę działaczy związanych z Piaseckim jeszcze przed wojną w Ruchu Narodowo-Radykalnym „Falanga” (m.in. Jerzy Hagmajer, Zygmunt Przetakiewicz, Ryszard Reiff); 2) środowisko tych, którzy współpracę podjęli z nim w latach II wojny światowej (m.in. Kętrzyński, Horodyński); 3) działaczy katolickich, dla których działalność w przyszłym Paxie była pierwszym poważnym doświadczeniem politycznym (m.in. Micewski, Mazowiecki, Zabłocki); 4) wywodzących się z grupy „Buntu Młodych” i „Polityki” „młodokonserwatystów”-,,mocarstwowców", poruszających się najpierw w nurcie politycznego realizmu, lecz następnie ewoluujących w kierunku wieloaspektowej afirmacji rzeczywistości pojałtańskiej (m.in. Bocheński, Frankowski, Łubieński).

Liderzy „secesji” nie zaliczali się do kręgu przedwojennych współpracowników Piaseckiego, wiążąc się z nim w latach II wojny światowej (Horodyński, Kętrzyński) lub dopiero po niej (Bocheński), nie zawsze już w 1945 r. (Micewski, Łubieński, Frankowski). Ich związek z „Dziś i Jutro” był więc wyborem nie wiernych akolitów niedawnego wodza Falangi, ale skutkiem bardziej indywidualnych przemyśleń.

Totalizacja życia politycznego w pierwszej połowie lat pięćdziesiątych zahamowała na krótko proces krystalizowania się różnych nurtów

J. Turowicz, S. Stomma, Katolicy w Polsce Ludowej, TP 1950, 50, s. 3-4; iidem, Eksperyment polski, TP 1952, 5, s. 1-2; P.H. Kosicki, op. cit., s. 207-214; M. Strzelecka, Między minimalizmem a maksymalizmem. Dylematy ideowe Stanisława Stommy i Janusza Zabłockiego, Toruń 2015, s. 85-99 (tutaj też analiza dyskusji prasowej wokół tekstu Stommy); R. Ptaszyński, Stommizm. Biografia polityczna Stanisława Stommy, Kraków 2018, s. 106-112.

15 A. Friszke, Opozycja polityczna w PRL 1945-1980, Londyn 1994, s. 190-192. 
w grupie „Dziś i Jutro” (występującej od 1952 r. pod formalną nazwą Stowarzyszenia „Pax”). Podskórnym procesom rozłamowym sprzyjała „odwilż”, pomimo „frondy” w 1955 r. ${ }^{16}$ Katalizatorem kolejnego kryzysu stała się publikacja artykułu Piaseckiego Instynkt państwowy ${ }^{17}$. Był on oczywistym manifestem sprzeciwu autora wobec toczących się przemian politycznych, wykluczającym się z poglądami znaczącej części zespołu. W istocie jednak lider Paxu już od wiosny 1956 r., odcinając się od „wypaczeń”, jednocześnie przestrzegał przed „wrogami” socjalizmu ${ }^{18}$. Poglądy te spotkały się z ostrą krytyką prasy „odwilżowej” i środowisk intelektualnych ${ }^{19}$. Piasecki bronił się, twierdząc, że sprzeciwiał się jedynie krytykowaniu „systemu sojuszy” i „budownictwa socjalistycznego"20.

Na zebraniu kierownictwa Stowarzyszenia 21 października 1956 r. m.in. Frankowski, Łubieński, Horodyński, Kętrzyński i Micewski domagali się demokratyzmu w zarządzaniu i czasowego odsunięcia Piaseckiego od kierownictwa. Mieli oni silne wsparcie wśród "młodych działaczy” zgromadzonych w redakcjach „Kierunków” i „Słowa Powszechnego”. Piasecki, chociaż niepewny swej pozycji, domagając się wotum zaufania, postawił przeciwników w trudnej sytuacji. Jak zauważał na bieżąco Zabłocki, a po latach Micewski, „hamletyzowali” oni, starając się pogodzić obronę dobrego imienia przywódcy z krytyką jego linii politycznej, co wynikało także z ich przeszłości politycznej. W efekcie Piasecki stanowisko utrzymał (116 głosów za na 146 oddanych), ale wybrane 28 października prezydium dawało opozycjonistom niewielką jedynie przewagę. Piasecki, zdając sobie sprawę z poparcia Władysława Gomułki (wiedział o nim od Walerego Namiotkiewicza), wycofał się tymczasem z propozycji, ażeby jego przeciwnicy otrzymali tygodnik „Kierunki”. Pat, jaki zaistniał w Stowarzyszeniu w pierwszej dekadzie listopada, przeciął, wbrew woli kolegów, Kętrzyński, wysyłając list

${ }^{16}$ T. Sikorski, Fronda. Rozłam w Stowarzyszeniu Pax w 1955 roku. (Geneza - przebieg konsekwencje), DN 2018, 1, s. 201-227.

17 B. Piasecki, Instynkt państwowy, SP 1956, 248, s. 3. Ton artykułu łagodziła nieco kolejna wypowiedź szefa Paxu: idem, Warunki dialogu, SP 1956, 252, s. 1.

18 B. Piasecki, Konsekwencje, SP 1956, 125, s. 4-5; idem, Założenia, ŻiM 1956, 5, s. 259 264; idem, Rzeczywista demokratyzacja i Front Narodowy, SP 1956, 194, s. 3.

19 ŻiM, 1956, 5, s. 277-298, 302-307, 310-330, 342-351; 1957, 1, s. 193-195, 204-205, 207-217; Pokłosie niefortunnego wystapienia p. Bolesława Piaseckiego [przedruk z „Expressu Wieczornego"], ŻiM 1956, 5, s. 298; Oświadczenie pisarzy i działaczy katolickich [przedruk z „Życia Warszawy”], ŻiM 1956, 5, s. 300; Literaci warszawscy domagaja się odwołania B. Piaseckiego z Prezydium Ogólnopolskiego Komitetu Frontu Narodowego [przedruk z „Expressu Wieczornego"], ŻiM 1956, 5, s. 301.

${ }^{20}$ Fragment oświadczenia Bolesława Piaseckiego, ŻiM 1956, 5, s. 354-355. 
do partii z prośbą o mediację. W obliczu tego Piasecki zajął nieprzejednane stanowisko ${ }^{21}$.

Secesjoniści wydawali się mieć początkowo duże szanse na powodzenie. Edward Ochab zapewniał Frankowskiego, Łubieńskiego i Horodyńskiego, że Pax zostanie rozwiązany, a Piaseckiemu pozostawione jedynie „Kierunki”. Jego rozmówcy mieliby otrzymać do dyspozycji „Słowo Powszechne", pozostałe zaś agendy Paxu przejęłaby grupa odnowionego „Tygodnika Powszechnego"22. Władysław Bieńkowski, jak wynika z zapisów Jerzego Zawieyskiego, był zwolennikiem szybkiej likwidacji Stowarzyszenia, a w zamiarach tych tonować musieli go twórcy grupy Znak ${ }^{23}$. Stanowisko Gomułki w sprawie Piaseckiego było ewidentnie sprzeczne z opinią jego bliskich współpracowników.

Rozłam stał się faktem 11 listopada 1956 r. Piasecki, deklaratywnie aprobując „polską drogę do socjalizmu”, atak na siebie przedstawił jako działanie „sił zakulisowych". Czując wagę swej pozycji w Stowarzyszeniu, złożył wniosek o wyrażenie wotum nieufności wybranemu dwa tygodnie wcześniej prezydium, który zyskał znaczną aprobatę. On sam otrzymał wotum zaufania przygniatającą większością, nowe prezydium składało się zaś z jego zdecydowanych zwolenników. 10 listopada Frankowski napisał list do „Trybuny Ludu” (opublikowany trzy dni później), w którym poinformował o swoim odejściu ze Stowarzyszenia, motywując to brakiem jawności i zasad demokratycznych w zarządzaniu i wzywał katolików świeckich do zaangażowania się, w ramach Frontu Narodowego, w działalność polityczną i „odwilżową”. W ślad za nim Stowarzyszenie opuścili inni opozycjoniści ${ }^{24}$.

"Oczyszczony” z kontestatorów Pax, epatując hasłami o moralności życia publicznego, powoływał się na „najwyższe autorytety społeczne”,

${ }^{21}$ Plenarne zebranie Zespołu Stowarzyszenia „Pax”, „Kierunki” 1956, 25, s. 1; „Pax” obraduje, SP 1956, 261, s. 3; List grupy młodych dziennikarzy ze „Słowa Powszechnego”, „Sztandar Młodych” 1956, 238, s. 2; Burza na Mokotowskiej. Liczne dymisje w „Pax” [przedruk z Życia Warszawy], ŻiM 1956, 5, s. 340-341; K. Eberhardt, J. Krzysztoń, Z. Laskowski, S. Lichański, A. Morawska, W.L. Terlecki, J. Weyroch, W sprawie „Kierunków” [przedruk z „Po Prostu”], ŻiM 1957, 1, s. 205-206; J. Zabłocki, Dzienniki, s. 37; A. Micewski, Współrzadzić czy nie kłamać? Pax i Znak w Polsce 1945-1976, Kraków 1981, s. 86-90; A. Dudek, G. Pytel, Bolesław Piasecki. Próba biografii politycznej, Londyn 1990, s. 236-246; A. Friszke, Nadzieje i złudzenia, s. 101.

22 J. Zabłocki, Dzienniki, s. 53; A. Micewski, Wspótrządzić czy nie kłamać, s. 90; A. Dudek, G. Pytel, op. cit., s. 247.

${ }^{23}$ A. Friszke, Nadzieje i złudzenia, s. 92; J. Zawieyski, Dzienniki, t. 1: Wybór z lat 19551959, Warszawa 2011, s. 307-308.

${ }^{24}$ Plenarne zebranie zespołu Stowarzyszenia „Pax”, SP 1956, 272, s. 1; J. Frankowski, W zwiazku z artykułem p. Bolesława Piaseckiego, „Trybuna Ludu” 1956, 316, s. 3; A. Dudek, G. Pytel, op. cit., s. 248-249. 
które posiadają wiedzę na temat genezy „ruchu społecznie-postępowego" mogącą obalić rozmaite „inwektywy” w tej dziedzinie. Mając na uwadze rolę Gomułki w procesie powstania grupy „Dziś i Jutro” w 1945 r., nie można mieć wątpliwości, że to jego paksowcy mieli na myślii ${ }^{25}$.

18 listopada 1956 r. w sali Zrzeszenia Prawników w Warszawie odbyło się zebranie Tymczasowego Komitetu Porozumiewawczego Działaczy Katolickich przy Ogólnopolskim Komitecie Frontu Narodowego. Jego przewodniczącym został Frankowski, sekretarzem generalnym zaś Łubieński. Wkrótce powołano też Chrześcijański Instytut Społeczny (ChIS, znany też jako Instytut Chrześcijańsko-Społeczny) ${ }^{26}$. Powierzenie kierownictwa Frankowskiemu wynikało, jak wspominał Micewski, z jego powiązań z puławianami ${ }^{27}$.

W grudniu 1956 r. na łamach „Życia Warszawy” ukazał się list Horodyńskiego, Kętrzyńskiego, Łubieńskiego i Micewskiego, a także osobny artykuł tego ostatniego. Secesjoniści odcinali się od zarzutów, że chcą przejąć Pax środkami administracyjnymi. Uważali się natomiast za reprezentantów tych wszystkich, którzy byli przeciwni linii Piaseckiego. W istocie jednak mogli jedynie protestować i krytykować swego niedawnego przywódcę. Piasecki u schyłku 1956 r. w zasadzie całkowicie opanował sytuację wewnątrz organizacji, wkrótce zaś miał też uzyskać jednoznaczne wsparcie samego Gomułki ${ }^{28}$. Wszystkie inicjatywy secesji zostały oczywiście napiętnowane na łamach „Słowa Powszechnego"29.

${ }^{25}$ AIPN, 0648/169/2, „Doniesienie agenturalne” [źródło: „Czechowski”], 2 III 1957, k. 29; Zwycięstwo prawdy, SP 1956, 255, s. 1-2; J. Gajdziński, W sprawie Paxu, SP 1956, 263, s. 4; Oświadczenie Stowarzyszenia Pax, ŻiM 1956, 5, s. 356; B. Piasecki, Na drogach odnowy, SP 1956, 277, s. 3; idem, Tło ideowo-polityczne polskiej drogi do socjalizmu, ŻiM 1957, 1, s. 175-181; idem, O socjalistycznym zaangażowaniu narodu, ŻiM 1957, 1, s. 181-193.

26 AIPN, 0648/169/1 [sprawa operacyjnego rozpracowania ChSS], Notatka dot. ChSS, k. 106; ibidem, Informacja dot. działalności ChSS, k. 116; Chrześcijańskie Stowarzyszenie Społeczne, „Za i Przeciw” (dalej: ZiP) 1957, 32, s. 5.

27 A. Micewski, Katolicy w potrzasku. Wspomnienia z peryferii polityki, Warszawa 1993, s. 47-48.

${ }^{28}$ D. Horodyński, W. Kętrzyński, K. Łubieński, A. Micewski, W odpowiedzi Janowi Dobraczyńskiemu [przedruk z „Życia Warszawy”], ŻiM 1957, 1, s. 195-196; A. Micewski, Pierwsze rewizje [przedruk z „Życia Warszawy”], ŻiM 1957, 1, s. 196-199; J. Frankowski, S. Dolański, K. Dziembowski, T. Przeciszewski, K. Łubieński, Oświadczenie działaczy katolickich [przedruk z „Życia Warszawy”], ŻiM 1957, 1, s. 199-200; D. Horodyński, W. Kętrzyński, K. Łubieński, A. Micewski, A. Morawska, A. Romaniuk, J. Weyroch, Rezolucja byłych działaczy i pracowników Paxu [przedruk z „Życia Warszawy”], ŻiM 1957, 1, s. 201-202. Skrótowe przedstawienie całej sprawy: A. Friszke, Opozycja polityczna, s. 189-190.

${ }^{29}$ J. Hagmajer, W imię jawności, SP 1956, 204, s. 2; (Z.J.), Nasza odpowiedź, SP 1956, 302, s. 4. 
Powołanie tygodnika „Za i Przeciw” i dyskusja

Nowe środowisko nie potrafiło początkowo zdecydować o swej formie organizacyjnej, co wynikało z nadziei na całkowite przejęcie Paxu. Frankowski łudził się, że ChIS i Komitet Porozumiewawczy zajmą w Komisji Porozumiewawczej Stronnictw Politycznych miejsce ruchu Piaseckiego. Postulowano wprowadzenie do sejmu 12 posłów, tymczasem, za zgodą władz, udało się wejść jedynie trzem (Łubieńskiemu, Mironowi Kołakowskiemu oraz Frankowskiemu, nie udało się uzyskać „mandatowego” miejsca dla Horodyńskiego, Kętrzyński zaś, Tadeusz Kłosiński i Aleksander Siebert kandydowali z miejsc „niemandatowych”). Frankowski nie zdołał też stanąć na czele jednolitej reprezentacji posłów katolickich, ani nawet uzyskać zgody na włączenie siebie oraz Łubieńskiego do Znaku Stanisław Stomma nie chciał na razie brać pod swoje skrzydła byłych prominentnych paksowców. Do Znaku „zdezerterował” za to, jeszcze przed formalnym rozpoczęciem prac Sejmu, Kołakowski. U progu nowej kadencji Sejmu „secesjoniści” byli więc „posłami dzikimi”"30.

Na początku 1957 r. Frankowski i jego akolici spotkali się z sekretarzem Komitetu Centralnego, Jerzym Morawskim, który obiecał im koncesję na wydawanie tygodnika społeczno-politycznego, zgodę na utworzenie organizacji podobnej do Paxu oraz przejęcie spółki Ars Christiana ${ }^{31}$. $\mathrm{Na}$ tej podstawie snuto projekt powołania Stowarzyszenia Chrześcijańsko-Postępowego lub Związku Chrześcijańsko-Społecznego oraz oparcia go o nowe czasopismo, zatytułowane „Za i Przeciw”. Frankowski chciał ewidentnie „uciec do przodu" wobec rysującego się fiaska jego koncepcji politycznej - coraz silniejsze były głosy krytyczne wobec jego przywództwa, jedynym zaś „sukcesem”, który wzbudzał jednak negatywne komentarze, było opanowanie Ars Christiana (spółka ta była wydzierżawiona

${ }^{30}$ AAN, Urząd do spraw Wyznań (dalej: UdsW), 74/74, Pismo (prawdopodobnie) Jerzego Sztachelskiego do Zenona Kliszki dot. m.in. sytuacji środowisk katolickich w latach 1956-1957, 16 I 1961, k. 7-8; AIPN, 0648/169/2, „Doniesienie agenturalne” [źródło: „Czechowski”, dot. działalności secesji w latach 1956-1957], 2 III 1957, k. 29-32; ibidem, „Informacja na podstawie meldunku specjalnego z Rzeszowa” [dot. działalności secesji w 1957 r. i jej relacji ze środowiskiem Znaku], 5 III 1957, k. 33; J. Zabłocki, Dzienniki, s. 71-72; J. Zawieyski, op. cit., s. 346-347, 351-352; A. Friszke, Koło posłów „Znak” w Sejmie PRL 1957-1976, Warszawa 2002, s. 14-15; idem, Nadzieje i złudzenia, s. 101-102. Pełen rezerwy i nieufności stosunek do grupy Frankowskiego został wyrażony w pierwszym numerze „odzyskanego” „Tygodnika Powszechnego”, J. Woźniakowski, Kluby Inteligencji Katolickiej, TP 1956, 1, s. 7.

31 AAN, Polska Zjednoczona Partia Robotnicza. Komitet Centralny w Warszawie (dalej: KC PZPR), V-52, „Postulaty grupy działaczy skupionych wokół tygodnika «Za i Przeciw»", 24 V 1957, k. 217; A. Friszke, Nadzieje i złudzenia, s. 102-103. 
przez Caritas, jej udziałowcami byli publicyści „Za i Przeciw”, jednak Pax, mający duży wpływ na Caritas, starał się anulować tę decyzję). Za złudne należało też uznać nadzieje na trwały sojusz „secesji” z „niedobitkami” niezależnych chadeków, na czele z Wacławem Bitnerem i Kazimierzem Studentowiczem. Ci ostatni mieli spore ambicje, a chociaż zawierzyli je, nie bez oporów, Frankowskiemu, ten nie potrafił uzyskać dla nich mandatów poselskich ${ }^{32}$.

3 marca 1957 r. podjęto decyzję o powołaniu Związku Chrześcijańsko-Społecznego, który znany był też pod nazwą Chrześcijańskiego Związku Społecznego i Chrześcijańskiego Towarzystwa Społecznego, na czele z Frankowskim, Łubieńskim, Horodyńskim, Micewskim, Janem Meysztowiczem i Sewerynem Dolańskim. Nowa organizacja miała zastąpić Komitet Porozumiewawczy. Spotkanie założycielskie obfitowało w „odwilżowe” i antypaksowskie deklaracje, o dość ogólnym jeszcze charakterze. 8 marca Łubieński, Frankowski i Dolański zostali przyjęci przez sekretarza Episkopatu biskupa Zygmunta Choromańskiego. Wbrew deklaracjom Frankowskiego organizacji nie udało się zalegalizować z powodu niechęci PZPR, obawiającej się, że nowe ugrupowanie stanie się ekspozyturą wpływów chadeckich (nadzieje na legalizację pojawiły się w maju 1957 r., kiedy Piasecki wywołał kolejne niezadowolenie komunistów artykułem w „Słowie Powszechnym”)33. Jej zasadniczym

32 AAN, KC PZPR, V-52, „Postulaty grupy działaczy skupionych wokół tygodnika «Za i Przeciw»", 24 V 1957, k. 217; ibidem, Archiwum Rodziny Rostworowskich (dalej: ARR), 241, Opracowanie Jana Majdeckiego dotyczące powstania ChSS, 1977, b.pag.; ibidem, 255, Projekty uchwał ZG ZK „Caritas” w sprawie „Ars Christiana”, VIII 1957, b pag.; AIPN, 0648/169/2, „Doniesienie agenturalne” [źródło: „Czechowski”], 2 III 1957, k. 29-32; ibidem, „Doniesienie informacyjne. Grupa posła Frankowskiego. Związek Chrześcijańsko-Społeczny” [źródło: „Stefan”], 18 III 1957, k. 38-39; ibidem, 0648/86/1 [materiały dot. środowisk chadeckich], „Notatka służbowa z odbytego spotkania z agentem „Żarskim”, 24 XI 1956, k. 180-184; A. Friszke, Nadzieje i złudzenia, s. 102-103. Jak trafnie pisał o ChIS-ie Jerzy Krasnowolski, ,grupa ta ma te samy mankamenty, co Pax, nie ma natomiast najważniejszego atutu, jakim jest Bolesław Piasecki”, AAN, UdsW, 129/6, J. Krasnowolski, „Problem działalności społecznie postępowej katolików na tle sytuacji wyznaniowej w Polsce w r. 1957", 7 V 1957, k. 22.

33 AIPN, 0648/169/1, „Lista założycieli Stowarzyszenia pod nazwą Chrześcijański Związek Społeczny”, k. 8; ibidem, „Lista założycieli Stowarzyszenia pod nazwą Chrześcijańskie Towarzystwo Społeczne”, k. 14-15; ibidem, „Lista członków założycieli Stowarzyszenia pod nazwą Chrześcijańskie Towarzystwo Społeczne”, k. 17; ibidem, 0648/169/2, „Informacja”, 16 III 1957, k. 36; ibidem, „Doniesienie informacyjne. Grupa posła Frankowskiego. Związek Chrześcijańsko-Społeczny” [źródło: „Stefan”], 18 III 1957, k. 38-39; ibidem, „Doniesienie informacyjne dot. środowiska skupionego wokół tygodnika «Za i Przeciw»” [źródło: „Stefan”], 5 VI 1957, k. 57; A. Friszke, Nadzieje i złudzenia, s. 103-104. 
celem miało być: „prowadzenie pracy społeczno-politycznej, dla włączenia najszerszych mas do aktywnego budownictwa ustroju sprawiedliwości społecznej w Polsce w oparciu o zasady nauki i etyki chrześcijańskiej"34.

Wobec trudności w legalizacji, w kwietniu Frankowski, Horodyński, Kętrzyński i Micewski złożyli na ręce Zenona Kliszki memoriał mówiący o konieczności oparcia pracy środowisk katolików świeckich o zasadę niezależności od Episkopatu w kwestiach politycznych, ale i unikania konfliktu z duchowieństwem w kwestiach wyznaniowych ${ }^{35}$. Było jasne, że wobec wieloznaczności tej deklaracji faktycznym wyznacznikiem linii politycznej grupy będzie jej publicystyka.

Pierwszy numer „Za i Przeciw” ukazał się 24 marca 1957 r. (przedtem rozpoczęto wydawanie skierowanego do Polonii i redagowanego przez Frankowskiego miesięcznika „Hejnał Mariacki”36). Periodyk do numeru 24 z 1 września 1957 r. był redagowany przez kolegium w składzie: Frankowski, Horodyński, Kętrzyński, Micewski, Łubieński, a także Meysztowicz, Kazimierz Dziembowski, Stanisław Grochowiak, Tadeusz Kłosiński, Stefan Kurowski, Anna Morawska, Adam Romaniuk, Wiesław Sachs, Jacek Wejroch, Zbigniew Zaborski (nieco wcześniej ze stopki wykreślone zostało nazwisko Kętrzyńskiego, nie wydaje się być to jednak faktem istotnym wobec znaczenia programowych artykułów tego ostatniego) ${ }^{37}$. Pismo, na tle prasy środowisk katolików świeckich, wyróżniało się bardzo atrakcyjną formą - obok rozważań społeczno-politycznych i artykułów dotyczących kwestii religijnych znalazły w nim też miejsce rubryki typowe dla pism popularnych, nastawionych na masowego odbiorcę. Systematycznie zwiększało liczbę kolorowych stron. Pod względem atrakcyjności formy na rynku prasy katolickiej mogło konkurować w tym czasie jedynie z ukazującą się od lutego 1957 r. „Zorzą Świąteczną”, „Za i Przeciw" było jednak od niej lepiej redagowane aż do 1963 r. i reformy tego pierwszego periodyku. Stąd też pismo grupy Frankowskiego mogło kierować swój przekaz nie tylko do sympatyków „secesji” czy zaangażowanych publicznie katolików, ale i do prowincjonalnego laikatu

${ }^{34}$ AIPN, 0648/169/1, „Statut Stowarzyszenia pod nazwą Chrześcijański Związek Społeczny", k. 9.

35 A. Friszke, Nadzieje i złudzenia, s. 105. Odmowę legalizacji Chrześcijańskiego Związku Społecznego tłumaczono obawami przed odrodzeniem się w jej postaci ruchu chadeckiego. AAN, KC PZPR, V-52, „Notatka informacyjna w sprawie «Chrześcijańskiego Związku Społecznego»", k. 203-204.

36 J. Frankowski, Na progu Nowego Roku, „Hejnał Mariacki” 1957, 1, s. 2; idem, Nasze stosunki z polonia, ZiP 1957, 5-6, s. 2-3.

37 ZiP 1957, 1, s. 15; 4, s. 15; 24, s. 14. 
i kleru, chociaż nie rościło sobie pretensji do miana reprezentanta wierzących w Polsce ${ }^{38}$.

Pismo było „Za” linią „odwilży” politycznej i jej kontynuacją w „,warunkach pełnej demokracji” i „polskiej drogi do socjalizmu”. To ostatnie rozumiano jako system dążący do „sprawiedliwości społecznej”. Niemniej, popierano prywatną własność środków produkcji w rolnictwie, rzemiośle, drobnym przemyśle i handlu, dość ogólnikowo aprobowano rady robotnicze i z wielką satysfakcją witano poprawę relacji państwo-Kościół. Podkreślano też znaczenie swobody dyskusji ideowej. Oczywiście, zespół dokonywał afirmacji „sojuszu” polsko-sowieckiego jako wymogu narodowej racji stanu, także w kontekście problemu granicy zachodniej. Domagano się jednak od wschodniego sąsiada zrozumienia „polskiej specyfiki”, od Polaków zaś uznania geopolitycznych realiów i porzucenia maksymalistycznych koncepcji, co w tym aspekcie sytuowało pismo blisko modelu realizmu zaproponowanego we wspomnianym już tekście Stommy. Grupa była zaś „Przeciw” wszelkim przejawom „totalizmu” i błędom niedawnej epoki stalinizmu, które jednak, zdaniem redakcji, nie świadczyły negatywnie o samej teorii Marksa i Engelsa ${ }^{39}$. Było to zgodne $\mathrm{z}$ deklaracją Łubieńskiego na zebraniu grupy 8 grudnia 1956 r., kiedy mówił o czterech zasadniczych założeniach, jakie „secesja" wyciągnęła z Października. Były to: faktyczna niezależność i suwerenność, demokratyzacja życia społecznego, rehabilitacja ofiar represji i racjonalizacja zarządzania gospodarką ${ }^{40}$.

Fakt dokonania „secesji” tłumaczono dyktatorskim stylem zarządzania Piaseckiego oraz jego postawą wobec „odwilży” i Kościoła. Tę ostatnią krytykowano jako „błędną interpretację pośrednictwa”, przy

38 AAN, UdSW, 74/74, Pismo do Zenona Kliszki, 16 I 1961, k. 9-10. Władze były zirytowane dewocyjnymi treściami tak w „Za i Przeciw”, jak i w „Zorzy”. AAN, UdsW, 129/6, Wytyczne Wydziału Administracyjnego KC PZPR w sprawie grup katolickich, II 1961, k. 3; AAN, KC PZPR, 237/XIX-171, „Załącznik 3 prasy Pax”, 19 III 1960, k. 41-42; ibidem, B. Gołębiowski, „Notatka w sprawie prasy katolickiej”, 6 III 1961, k. 71.

39 Zespół „Za i Przeciw” [Deklaracja], ZiP 1957, 1, s. 1-2. Stosunek grupy do problemu suwerenności bliski był tezie, wyrażonej przez Piaseckiego już w artykule wstępnym w pierwszym numerze „Dziś i Jutro”, który pisał o „rodzimej rewolucji” i konieczności zrozumienia potrzeby „sojuszu” ze wschodnim sąsiadem, co wynikać miało ze świadomości jego potencjału. Jak się wydaje, „secesjoniści” poglądu tego nie odrzucili nigdy, uznając go w dobie „odwilży” za bardzo atrakcyjny, mniej pisząc może o geopolitycznych zagrożeniach, a więcej o szansach, wynikających z przyjęcia realistycznej postawy wobec Związku Sowieckiego. Por.: B. Piasecki, Zagadnienia istotne, Dij 1945, 1, s. 1. Programowy tekst grupy i pierwszy numer czasopisma z pewną dozą życzliwości przyjął „Tygodnik Powszechny”. Z dnia, TP 1957, 13, s. 2.

${ }^{40}$ A. Friszke, Nadzieje i złudzenia, s. 101. 
nieposłuszeństwie wobec Watykanu (sprawa indeksu watykańskiego dla „Dziś i Jutro” oraz Zagadnień istotnych w 1955 r.) i monopolizowaniu życia politycznego polskich katolików. Z rezerwą natomiast należy odnieść się (mając na uwadze wcześniejsze nadzieje „secesji” na przejęcie całego Stowarzyszenia) do stwierdzenia, że Pax zaatakowano poważnie dopiero w marcu 1957 r., gdyż nie chciano angażować się we wcześniejszą kampanię prasy lewicowej ${ }^{41}$. Dodać przy tym należy, że antypaksowskie ostrze artykułów z pierwszego numeru zostało stępione przez cenzurę, która obawiała się „zupełnego rozłożenia” ruchu Piaseckiego. Było to widomym dowodem na rosnącą pozycję Paxu w oczach władz ${ }^{42}$.

Kolejny atak nastąpił dwa miesiące później. W utrzymanym w oskarżycielskim tonie Ostrzeżeniu zespół tygodnika oskarżał Piaseckiego o wsparcie sił dogmatycznych w partii, negowanie zdobyczy październikowych, wreszcie denuncjację społeczeństwa polskiego wobec Związku Sowieckiego poprzez wysuwanie oskarżeń o poglądy antysocjalistyczne. Sugerowano, że przywódca Paxu liczy na sowiecką interwencję (co było nadużyciem), trafnie stwierdzając, że jego próby wiązania się z siłami zachowawczymi oraz kreowania się na jedynego rzecznika realizmu politycznego w Polsce są skutkiem jego nadmiernych ambicji tak politycznych, jak ideologicznych ${ }^{43}$. W podobnym tonie skrytykował wówczas Piaseckiego Jerzy Turowicz w „Tygodniku Powszechnym”44.

Jeszcze dalej w swej krytyce poszedł Kętrzyński, deprecjonując nie tylko Piaseckiego, ale i sam Pax. Stwierdzał, że Stowarzyszenie, mimo pewnych zasług kulturalnych, musi być oceniane przez pryzmat szkód, jakie wyrządziło interesom narodowym i katolickim. Nie potrafiło ono połączyć sprawy „budowania ludowej Polski” ze służbą Kościołowi. Pax miał być przy tym także „antypostępowy”, co udowodnił swą postawą w dobie Października. Z racji potencjału finansowego i organizacyjnego miał stanowić zagrożenie dla procesów demokratyzacji. Szermując hasłami katolicyzmu i realizmu politycznego (który Kętrzyński traktował w tym konkretnym wypadku jako oportunizm), Stowarzyszenie gromadziło działaczy, którym obca była w istocie sprawa „polskiej drogi do socjalizmu". Stało się wobec tego forum współpracy intelektualistów mających skłonności do "totalistycznego doktrynerstwa” oraz konserwatywnej, „realistycznej” właśnie prawicy społecznej. Wszystko to sprawiało, że Pax był „skrzydłem dogmatyzmu socjalistycznego w Polsce”,

${ }^{41}$ [Oświadczenie] ZiP 1957, 1, s. 4.

42 AIPN, 0648/169/2, „Doniesienie” [źródło: Górski”], 21 III 1957, k. 45-47.

${ }^{43}$ J. Frankowski, D. Horodyński, W. Kętrzyński, K. Łubieński, A. Micewski, A. Morawska, Ostrzeżenie, ZiP 1957, 9, s. 1.

${ }^{44} \mathrm{~J}$. Turowicz, Instynkt państwowy po raz drugi, TP 1957, nr 21, s. 4. 
a jego osłabienie było zgodne $\mathrm{z}$ interesem społecznym i katolickim ${ }^{45}$. Także Łubieński, broniąc ChIS-u przed zarzutami o bezprawne przejęcie Ars Christiana, wskazywał na dyktatorskie zapędy Piaseckiego i brutalne metody walki politycznej ${ }^{46}$.

W stopniu o wiele bardziej przyjaznym „Za i Przeciw”, piórem Kętrzyńskiego, odnosiło się do neopozytywizmu „Tygodnika Powszechnego”. Zgodnie z potocznym postrzeganiem minimalizmu rozumiano go jako pragmatyzm wobec geopolitycznych realiów i neutralność wobec sporu ideologicznego marksizmu i katolicyzmu. Jeśli „Tygodnik Powszechny” w nowych uwarunkowaniach podtrzymywał to stanowisko, oznaczało to, że nie będzie dla grupy „secesji” konkurentem w kwestiach ideowych ${ }^{47}$. Nie porzucała ona bowiem myśli o współpracy komunistów i katolików. Jej podstawą miała stać się normalizacja relacji państwo-Kościół. Zaborski pisał wprost o konieczności zerwania z „autokratyzmem ateistów”48. Podobnie sprawę stawiał Frankowski ${ }^{49}$. Kętrzyński, jak już wspomniałem, konstatował istnienie dwóch rozbieżnych światopoglądów, ale też fakt wcześniejszych brutalnych ataków komunistów na Kościół przeciwstawiał się jednak przekonaniu o nieuchronnym starciu marksizmu i chrystianizmu. Dodać należy, że tezę tę głosili także akolici Piaseckiego przed i po 1956 r. Kętrzyński uważał, że metoda konfrontacji musi prowadzić do „totalizacji” tak jednej, jak i drugiej strony (obok marksistów

${ }^{45}$ W. Kętrzyński, Istnieje problem Paxu, ZiP 1957, 11, s. 1; idem, Trudna nowa droga, ZiP 1957, 21, s. 1.

${ }^{46}$ W czerwcu 1957 r. ukazał się na łamach „Słowa Powszechnego” artykuł Transakcja, którego autor posługiwał się pseudonimem „Jur” (mógł się pod nim kryć Jerzy Hagmajer, a w każdym razie informował on autora tekstu). Zarzucano w nim, że Frankowski z ramienia ChIS bezprawnie przejął Ars Christiana. Tymczasem, jak wskazywało „Za i Przeciw”, „transakcja” ta miała miejsce za wiedzą Prezydium Zarządu Caritas, którego sekretarzem był sam Hagmajer. On sam jednak twierdził, że stało się to za jego plecami. Jur, Transakcja, SP 1957, 194 [błąd w numeracji], s. 6; idem, Transakcji ciąg dalszy, SP 1957, 142, s. 3; K. Łubieński, Słowu Powszechnemu - w odpowiedzi, ZiP 1957, 13, s. 5.

${ }^{47}$ W. Kętrzyński, Trudna, nowa droga, ZiP 1957, 21, s. 1, 5. Stanowisko to zostało wyrażone już w grudniu 1956 r. przez Kisielewskiego, który pisał wprost o tym, że jest przeciwnikiem marksizmu, ale uznaje realia geopolityczne, oraz przez Stommę, który wskazywał na zgubność polityki powstańczej i „maksymalizmu”. Wkrótce potem Gołubiew podkreślał konieczność naprawy państwa, ale bez głębszych rozważań ideologicznych, podkreślając za to konieczność wsparcia przez katolików tego postulatu. S. Kisielewski, Dwugłos o idealizmie i realizmie w polityce. Czy neopozytywizm?, TP 1956, 1, s. 4-5; S. Stomma, Dwugłos o idealizmie i realizmie w polityce. Idea i siła, TP 1956, 1, s. 5-6; A. Gołubiew, Dlaczego bierzemy udział w sprawach politycznych?, TP 1957, 2, s. 1.

${ }^{48}$ Z. Zaborski, Polityka wielkiej szansy, ZiP 1957, 4, s. 5; idem, Siew październikowego ziarna, ZiP 1957, 12, s. 1, 4.

${ }^{49}$ J. Frankowski, Z teki poselskiej, ZiP 1957, 14, s. 3. 
doktrynerów istnieć też mieli katolicy zachowawcy, czyli antykomuniści). Katolicyzm tymczasem, wyłączając kwestie wiary i moralności, miał być otwarty na rozmaite ideologie i formy zaangażowania ${ }^{50}$. W miejsce teorii „dwóch obozów” środowisko „Za i Przeciw” proponowało zatem koncepcję dwóch współistniejących światopoglądów, twierdząc przy tym, że było to nieodzowne w warunkach polskich. Piasecki snuł koncepcję „wieloświatopoglądowości socjalizmu” jako skutku nieuchronnej sprzeczności inspiracji światopoglądowych marksizmu i chrystianizmu (materializm i spirytualizm), ale i przekonania o podobieństwie celów społecznych obu systemów myślowych. Celem ostatecznym miało być „przezwyciężenie zwycięzcy” (mówiąc kolokwialnie „ochrzczenie partii”, mówiąc praktycznie: rządy partii lewicy katolickiej), a w perspektywie bliższej współudział Paxu we władzy. „Za i Przeciw” nie przeczyło istnieniu sprzeczności między partyjnymi a bezpartyjnymi i możliwości współpracy, nie miało jednak tak wielkich ambicji politycznych, przy tym chyba bardziej realistycznie patrząc na rzeczywistość ${ }^{1}$.

Jednymi z najdojrzalszych, a także najbardziej krytycznych wobec linii Paxu wypowiedzi były teksty Micewskiego, uściślające konstatacje innych publicystów w dziedzinie relacji komuniści-katolicy. Autor krytykował w nich zarówno skłonność marksistów do tworzenia wielkiej, tłumaczącej wszelkie zjawiska doktryny, jak i próby niektórych katolików łączenia jej z chrystianizmem. Prowadziło to do doktrynerstwa, a w przypadku katolików także do relatywizmu i nihilizmu. Współpraca obu światopoglądów powinna wynikać nie z samej teologii, lecz zmysłu moralnego. Zmysł rzeczywistości natomiast (będący, jak twierdzi Piotr Kimla, jednym z wyznaczników politycznego realizmu ${ }^{52}$ ) nie mógł zezwolić na lekceważenie realiów geopolitycznych. Innymi słowy, można było nie być socjalistą, ale aprobować system jako polityczny realista. Droga „między dogmatyzmem a bezideowością" nie była propozycją budowy „socjalizmu wieloświatopoglądowego” („Nam chodzi nie o to,

50 W. Kętrzyński, o dwóch światopoglądach i o podziale na dwa obozy, ZiP 1957, 9, s. 3, 15. Por.: W. Chylicka, Polemiki na „miny”, ZiP 1957, 2, s. 1, 14. Tekst Kętrzyńskiego był polemiką z tezami Pawła Jasienicy, który sprzeciwiał się definiowaniu polskiego życia politycznego jako zdeterminowanego przez podział na obozy marksistowski i chrześcijański. W istocie koncepcja ta była punktem stycznym Paxu, „Za i Przeciw” oraz „Znaku”. P. Jasienica, Z dymem kadzidet, „Nowa Kultura” 1957, 22, s. 2; idem, Nawrócony, „Nowa Kultura" 1957, 18, s. 1; S. Stomma, Kompleksy czy zła wola? Odpowiedź Pawłowi Jasienicy, TP 1957, 20, s. 1; A. Kierys, Polska Jasienicy. Biografia publicysty, Kraków 2015, s. 474-479.

51 B. Bankowicz, Stowarzyszenie Pax, s. 37-48.

52 P. Kimla, Realizm z fałszywej analogii historycznej wywiedziony. Przypadek Ksawerego Pruszyńskiego, „Politeja” 2013, 25, s. 178-179. 
aby przyjmować taką czy inną część doktryny marksizmu-leninizmu i kojarzyć ją ze światopoglądem katolickim"), ale próbą pogodzenia wierności katolickim imponderabiliom i uznania pojałtańskich uwarunkowań. „Nie jest to żaden eklektyzm, tylko zdrowy empiryzm społeczny, kontrolowany normami moralności społecznej53" - konkludował autor. Dawało to jednak pewne pole do manewru w postaci popierania jednego z kierunków w polskim życiu politycznym. Micewski i inni publicyści środowiska jednoznacznie opowiadali się za wsparciem ruchu reformatorskiego $\mathrm{w}$ duchu inspiracji chrześcijańskiej i obiektywnie ocenianego socjalizmu. Wystrzegać się należało przy tym głoszenia przez katolików haseł czysto marksistowskich, co było nieautentyczne nawet dla samych komunistów. Zaangażowanie to, w formie „demokratycznej lewicy chrześcijańskiej", miało przybrać postać środowiska zaspokajającego potrzeby kulturalne i ideowe swego społecznego zaplecza oraz przyciągającego do swych haseł polskich katolików. Katolicy świeccy powinni być traktowani przez komunistów nie jako „mniej posłuszni marksiści”, lecz samodzielne środowisko polityczne. Dyskusja światopoglądowa była konieczna, ale powinna zakładać współistnienie, a nie eliminację czy podporządkowanie oponenta ${ }^{54}$.

To ostatnie zwłaszcza było jednak, jak zauważał Frankowski, utrudnione. Komuniści bowiem poprzez poparcie duchowieństwa dla ustroju rozumieli „zwożenie ich samochodami” na „szumne zjazdy”. Księża popierający ustrój narażali się na zarzut o zdradę. Jeśli natomiast ich

${ }^{53}$ Cyt.: A. Micewski, Między wszechwładza doktryny a bezideowościa, ZiP 1957, 8, s. 6. Por.: idem, Demokratyczna lewica chrześcijańska, ZiP 1957, 15, s. 1, 4; idem, Chrześcijaństwo, kultura, lewica..., ZiP 1957, 19, s. 1, 3. Wniosek o odejściu przez Micewskiego i secesję od „socjalizmu wieloświatopoglądowego" jest tym bardziej uzasadniony, jeżeli Micewski poprawnie rozumiał użyte w cytowanym sformułowaniu pojęcia (czyli „eklektyzm” jako próbę łączenia rozmaitych doktryn w celu ich pragmatycznego ujednolicenia, „empiryzm społeczny” zaś jako wyciąganie wniosków z doświadczenia rzeczywistości społecznej). Wydaje się zresztą, że poglądów zaprezentowanych wówczas Micewski nie wyrzekł się także i później. Por.: A. Micewski, Otwartość a lewicowość, „Więź” 1963, 2, s. 25-33; J. Didier, Słownik filozofii, Katowice 2006, s. 97, 100; B. Stanosz, Wstęp, w: Empiryzm współczesny, red. B. Stanosz, Warszawa 1991, s. 5-12; J. Eska, Kościół otwarty, Warszawa 1964, s. 47-56.

${ }^{54}$ A. Micewski, Między wszechwładzą doktryny a bezideowościa, ZiP 1957, 8, s. 1, 6; idem, Demokratyczna lewica chrześcijańska, ZiP 1957, 15, s. 1, 4; idem, Chrześcijaństwo, kultura, lewica..., ZiP 1957, 19, s. 1, 3; K. Łubieński, Słowu Powszechnemu - w odpowiedzi, ZiP 1957, 13, s. 5. Znowu o wiele bardziej wyważone w tej kwestii było stanowisko redakcji z Wiślnej. Gołubiew w jej imieniu pisał o konieczności tolerancji między przedstawicielami obu światopoglądów, przestrzegając przed powtarzaniem błędów epoki stalinizmu, wiosną 1957 r. zaś zwracano uwagę na możliwość i potrzebę „dialogu światopoglądowego”. A. Gołubiew, Kto sieje wiatr ten zbiera burze, TP 1957, 6, s. 1; Przeglad prasy, TP 1957, nr 15, s. 8. 
zaangażowanie polityczne miało odcień zbyt mało entuzjastyczny wobec polityki władz, groziły im krytyka, a nawet represje ze strony rządzących $^{55}$. Do aktywności politycznej katolików zachęcał także Zaborski, z dystansem spoglądając na refleksje rodzącego się ruchu klubowego o jego apolityczności. Rozumiał ją bowiem jako wyraz niechęci do pracy koncepcyjnej, którą uznawał za pożądaną (w przeciwieństwie do Kętrzyńskiego $)^{56}$.

Dodać przy tym należy, że spór o wzajemny stosunek chrystianizmu i marksizmu, kluczowy dla ideologii Stowarzyszenia „Pax”, nurtował środowiska katolickie już przed 1956 r. Najpełniejszym tego wyrazem była postawa Janusza Zabłockiego, który sprzeciwiał się „zanurzeniu” Kościoła w bieżących sporach politycznych i de facto podporządkowania im teologii i bieżącej działalności wspólnoty wierzących. Sprzeciw wobec tego, co „młodzi” w Paxie określali jako „integralny nacjonalizm” (postawę tę Piotr Kosicki trafnie określił jako „zwrot antymaurrasowski”), był potem jedną z przyczyn "frondy” w 1955 r. ${ }^{57}$ „Lewica bezpartyjna” zaś ewidentnie nawiązywała, jak wskazują powyższe refleksje Micewskiego, do tej koncepcji. Frankowski natomiast, mimo że zawsze podkreślał, iż katolicyzm nie jest tożsamy z jakimkolwiek ustrojem, nie wykluczał jego ścisłego związku z konkretnymi uwarunkowaniami. Aby zakończyć ten wątek, dodać należy, że także „Tygodnik Powszechny”, odżegnując się od myśli tworzenia własnego stronnictwa politycznego, stwierdzał rozbieżność katolicyzmu i polityki, był jednak niechętny programowym rozważaniom na temat pojęć „lewicy” i „demokracji”

Osobne zagadnienie w publicystyce tygodnika stanowiła ocena konkretnych przejawów politycznego zaangażowania bezpartyjnych i postaw społecznych w ogóle. Wstępnie konstatowano, że naturalne jest pewne rozluźnienie dyscypliny w momencie, gdy „przestał działać strach”. Niemniej, naród polski okazał się realistyczny, zgadzając się na niezadowalające jeszcze warunki życia i istniejące nadużycia, nie wysuwając haseł antyustrojowych, domagając się za to „prawdy” i „sprawiedliwości”59.

${ }^{55}$ J. Frankowski, Z teki poselskiej, ZiP 1957, 8, s. 4.

56 Z. Zaborski, Polityka wielkiej szansy, ZiP 1957, 4, s. 1. Por.: J. Woźniakowski, Kluby i polityka, TP 1957, 13, s. 1.

${ }^{57}$ J. Zabłocki, Katolicy wobec socjalizmu, SP 1951, 312, s. 5; idem, O jedność i transcendencje Kościoła. Przeciw wszelkim odmianom ,immanencji politycznej”, katolicyzmu, w: idem, Na polskim skrzyżowaniu dróg, Warszawa 1972, s. 121-137; P.H. Kosicki, op. cit., s. 375-387; M. Strzelecka, op. cit., s. 120-126; T. Sikorski, op. cit., s. 206-207.

58 „Król jest nagi”, TP 1957, 26, s. 4.

${ }^{59}$ J. Frankowski, D. Horodyński, W. Kętrzyński, K. Łubieński, A. Micewski, A. Morawska, Ostrzeżenie, ZiP 1957, 9, s. 1. 
Fakt, że hasła „totalnej negacji” ustroju nie były popularne (o czym świadczyły wybory do sejmu w styczniu 1957 r.) był szczególnie istotny w kontekście wydarzeń węgierskich. Mimo krytyki, jaka spadała na PZPR, publicyści traktowali ją jako rzeczywistą „reprezentację narodu”. Niemniej, istniała coraz wyraźniejsza wzajemna nieufność oraz rozbieżność między emocjami mas, a potrzebą realizmu, którego wyrazicielem miał być Władysław Gomułka ${ }^{60}$. Anna Morawska uznawała to za skutek „deficytu dyskusji” i rzetelnej krytyki prasowej oraz braku „wspólnego języka", czyli symptomów nawrotu do drętwej nowomowy i lekceważenia środowisk bezpartyjnych. Starano się to usprawiedliwiać hasłami walki $\mathrm{z}$,rewizjonizmem” $\mathrm{i}$ tendencjami antysocjalistycznymi, zdaniem Morawskiej jednak, postulaty decentralizacji czy zwiększenia roli rad robotniczych nie były „anarcho-syndykalizmem”, lecz wyrazem autentycznej troski bezpartyjnych o gospodarkę. Publicystka doskonale zdawała sobie sprawę, że pod hasłem „obrony socjalizmu” kryje się koncepcja ukrócenia październikowych zdobyczy ${ }^{61}$. Do tez tych nawiązywał Komentator, domagając się większej przejrzystości pracy sejmu oraz swobody dyskusji i głosowań w miejsce propagandowej „jednomyślności”"62. Zaborski krytykował natomiast biurokrację i poczucie bezkarności urzędników, apelując o zwiększenie faktycznej odpowiedzialności rządzących ${ }^{63}$. Przejawem śmiałości koncepcji było też wezwanie Frankowskiego do poszanowania prawa własności, co przejawiać się miało m.in. w wypłaceniu przewidzianych prawem odszkodowań dla tych, którzy swoja dobra stracili na skutek reformy rolnej ${ }^{64}$.

Obawy o zachowanie dorobku „odwilży” wyraził też Kętrzyński. Stwierdzał on restaurację natolińczyków, którzy stroili się w szaty obrońców doktryny. Podobnie jak Morawska pisał o rozchodzeniu się rządzących i rządzonych oraz zniechęceniu tych ostatnich. Tymczasem, jeśli Polacy mieli tworzyć swą własną drogę do socjalizmu, powinni być kimś więcej niż tylko „tłumem powiewającym czerwonymi sztandarami”. Dużą wagę

${ }^{60}$ Podobnie rezultat styczniowych wyborów komentował zespół „Tygodnika Powszechnego", podkreślając przy tym uznanie systemu socjalistycznego przy jednoczesnej rezerwie wobec ideologii marksistowskiej. Październik i styczeń, TP 1957, 5, s. 1-2.

${ }^{61}$ A. Morawska, Bezpartyjni, ZiP 1957, 1, s. 1, 4; Głos $w$ dyskusji przedzjazdowej, ZiP 1957, 28, s. 1, 14.

${ }^{62}$ Komentator, Pierwsze refleksje, ZiP 1957, 1, s. 6.

63 Z. Zaborski, Polityka wielkiej szansy, ZiP 1957, 4, s. 5. Por. K. Eberhardt, Sejmowe refleksje. $O$ posłach bezpartyjnych, ZiP 1957, 9, s. 2, 15.

${ }^{64}$ J. Frankowski, Z teki poselskiej, ZiP 1957, 9, s. 4; idem, Z teki poselskiej, ZiP 1957, 11, s. 4; idem, Z teki poselskiej, ZiP 1957, 13, s. 3. Por.: M. Wrzesz, Notatnik ożarowski czyli o smętnej wegetacji małego miasteczka, ZiP 1957, 16, s. 9-10. 
przywiązywał jednak do konieczności zrozumienia przez Polaków rozmaitych kompromisów, wynikających z uwarunkowań geopolitycznych ${ }^{65}$.

Micewski konstatował wzrastające niepokoje społeczne, określając je co prawda eufemistycznie "falą nastrojów pesymistycznych”. Uznawał to za wyzwanie dla „lewicy demokratycznej”. Tezy, że „polska rewolucja" zmierza w niebezpiecznym kierunku, były korzystne dla partyjnych konserwatystów oraz Paxu. Wobec tego to nurty reformatorskie powinny podjąć refleksję nad polską racją stanu, opierając się na autorytecie Gomułki. Nie uważał jednak, że reformom zagrażają śmiałe wypowiedzi „Po Prostu” czy innych pism kulturalnych. Obóz przemian, w tym także „Za i Przeciw”, powinien działać inspirująco na społeczeństwo, tak, aby swą postawą przeważył szalę zwycięstwa w sporze wewnątrzpartyjnym na rzecz „twórców Października”. Polacy mogli udowodnić, twierdził Micewski, że demokracja nie oznacza anarchii, lecz może być wyrazem politycznego realizmu. Publicysta zdawał sobie sprawę, że społecznemu niezadowoleniu sprzyjają trudności ekonomiczne. Konieczność wyrzeczeń mogła być przez obywateli zrozumiana tylko wówczas, jeśli zostaną im zagwarantowane wymierne swobody polityczne. Konstatacje Micewskiego w tej dziedzinie zwłaszcza zdradzały już jednak objawy pewnej teoretycznej bezradności wobec obserwacji bieżącej rzeczywistości ${ }^{66}$.

Jak wspomniałem, za ramy politycznego zaangażowania „bezpartyjnych” publicyści „Za i Przeciw” uznawali powojenne uwarunkowania geopolityczne. Kwestie te rozstrzygnął w zasadzie programowy artykuł zamieszczony w numerze drugim tygodnika. Wychodząc z założenia o dwubiegunowym podziale świata oraz hegemonii Związku Sowieckiego w Europie Środkowej, przyznawano, że dobre relacje PRL ze wschodnim sąsiadem wymagają pewnego ograniczenia suwerenności, jednakże w stopniu mniejszym, niż przed $1956 \mathrm{r} \cdot{ }^{67}$ Argumentacji dla tych tez Jan Meysztowicz szukał w epoce Stanisława Augusta. Oceniając pozytywnie

65 W. Kętrzyński, Realizm i wola mas, ZiP 1957, 3, s. 1-2; idem, Rządzacy i rządzeni, ZiP 1957, 8, s. 1, 4-5. Por.: Z. Zaborski, Polityka wielkiej szansy, ZiP 1957, 4, s. 5.

${ }^{66}$ A. Micewski, Demokratyczna lewica chrześcijańska, ZiP 1957, 15, s. 4; idem, Chrześcijaństwo, kultura, lewica..., ZiP 1957, 19, s. 3; idem, Od czego zależy dalsza demokratyzacja, ZiP 1957, 26, s. 1. Por.: (ja-we), ...po prostu czy polityka, ZiP 1957, 20, s. 3; S.J. Kurowski, Publicystyka i polityka, ZiP 1957, 27, s. 1, 15; A. Szmidt, Nie trzeba przymusu - wystarczy dobra organizacja, ZiP 1957, 28, s. 8; Jerzy Putrament rozmawia z przedstawicielem „Za i Przeciw” o sytuacji w publicystyce, ZiP 1957, 28, s. 8. „Tygodnik Powszechny”, konstatując w nieco bardziej zawoalowanej formie odwrót od idei Października, zwracał uwagę na trudności ekonomiczne i bezkarność nadużyć władzy. W rocznicę, TP 1957, 26, s. 3.

67 O polityce polskiej, ZiP 1957, 2, s. 1, 14. Zaborski pewne nadzieje wiązał z polityką Chińskiej Republiki Ludowej, były to jednak na łamach tygodnika koncepcje efemeryczne. Z. Zaborski, Polityka wielkiej szansy, ZiP 1957, 4, s. 5. 
politykę króla Poniatowskiego, który miał starać się nie dopuścić do koalicji prusko-rosyjskiej drogą oparcia się o Petersburg, krytykował, za Stanisławem Catem-Mackiewiczem, „sojusze egzotyczne”68.

Może najpełniejszym wyrazem realistycznej, ale i reformatorskiej orientacji grupy był artykuł wstępny z okazji święta 22 lipca. O Polsce dotychczasowej pisano, że nie była „łatwa”, lecz „ciężka i nieraz tragiczna”, wzbudzająca wątpliwości i „wystawiająca na ciężkie próby”. Morawska pisała w innym miejscu wręcz o tym, że na skutek rządów PZPR kraj „ucierpiał przecież niemało”, wtórowali zaś jej redakcyjni koledzy, stwierdzając, że jeszcze niedawno „trudno było być Polakiem”. Redaktorzy „Za i Przeciw” pisali przy tym dość otwarcie o niewielkiej popularności komunistów w pierwszych latach powojennych. Stwierdzali też jednak, że inna Polska jak „Polska Ludowa” nie była możliwa i nikt „w Polsce ani poza jej granicami nie znalazł żadnej realnej i rozsądnej alternatywy”. Krytykując zatem „to co złe i nieludzkie, absurdalne i w gruncie rzeczy wsteczne”, nawiązywać chciała „lewica bezpartyjna” do „postępowych" haseł manifestu Polskiego Komitetu Wyzwolenia Narodowego, których kontynuację widziała w duchu przemian październikowych ${ }^{69}$.

Symptomatyczne jest przy tym, że niewielką wage przywiązywano na łamach tygodnika do kwestii ekonomicznych. Szerzej na ten temat wypowiedział się jedynie Stefan Kurowski, ekonomista, krytykując „centralizm administracyjny”. Opowiadając się za „prawem wartości” czyli za zmniejszoną regulacją rynku przez państwo, narażał się rzecz jasna na zarzuty o „reakcyjność” i „rewizjonizm”, przyznawał jednak, że nie uznawał argumentów Marksa za czynnik rozstrzygający. Wypowiedź ta była najdalej posuniętym przejawem krytyki samych podstaw systemu ekonomicznego PRL ${ }^{70}$. Frankowski był rzecznikiem wsparcia państwa dla drobnych inicjatyw rzemieślniczych, krytykując niedawne jeszcze przypadki karania więzieniem wytwórców ${ }^{71}$. Łubieński krytykował dogmatyczność planów. Upominał się o interesy konsumentów i sprzeciwiał się wysokim nakładom na przemysł ciężki, a nowy plan gospodarczy określał mianem „żadnej rewelacji”72.

${ }^{68}$ J. Meysztowicz, O stolniku litewskim na londyńskim bruku, ZiP 1957, 3, s. 4-5. Por.: J. Mikke, Racja stanu czy oportunizm?, ZiP 1957, 3, s. 4-5.

69 [Trzynasty już raz...], ZiP 1957, 18, s. 1; A. Morawska, Bezpartyjni, ZiP 1957, 1, s. 1.

70 S.J. Kurowski, W odpowiedzi polemistom (1), ZiP 1957, 5-6, s. 6. W podobnym nurcie utrzymane były rozważania Kisielewskiego. S. Kisielewski, Dramat ekonomiczny, TP 1957, 2, s. 3, 7 .

71 J. Frankowski, Z teki poselskiej, ZiP 1957, 9, s. 4.

72 K. Łubieński, Uwagi o planie pięcioletnim, ZiP 1957, 17, s. 1, 8. Por.: idem, Na drodze wielkiego rozwoju, DiJ 1954, 14, s. 4. 
Dyskusję ideologiczną podsumowywał w zasadzie wspólny artykuł Łubieńskiego i Morawskiej z sierpnia 1957 r. Autorzy powtórzyli dotychczasowe zasady koncepcji „bezpartyjnej lewicy demokratycznej”, poddali jednak szerszej analizie to pojęcie, rozwijając tezy Kętrzyńskiego i Micewskiego. Bezpartyjnych, dowodzili, mogła konsolidować jedynie moralność chrześcijańska i personalizm, które oceniali wyżej niż marksistowski relatywizm i kolektywistyczny determinizm. Lewica demokratyczna zatem, jako sojusznik PZPR, musiała kierować się inspiracją teologiczną (ale nie zaangażowaniem w sprawy kościelne), jeśli chciała przyciągnąć Polaków do haseł warunkowanych tak geopolitycznym realizmem, jak i postępowym oglądem kwestii społeczno-ekonomicznych. Tym ostatnim poświęcono, w przeciwieństwie do innych tekstów programowych, dużo miejsca. Odrzucono liberalne poglądy Kurowskiego, dowodząc, że chociaż nawrót do kapitalizmu przyniósłby polepszenie wskaźników konsumpcji, to przełożyłoby się to pozytywnie jedynie na poziom życia nielicznych, upośledzając masy ponoszące koszty kolejnej gospodarczej rewolucji. Tymczasem faktyczna demokratyzacja, czyli zwiększenie partycypacji mas w rządzeniu, ale też upowszechnienie kultury wysokiej, pozwolą na powiązanie przez nie interesu osobistego z troską o progres ekonomiczny kraju. Dzięki faktycznej realizacji idei Października Polska mogła być inspiracją dla świata w dziedzinie syntezy takich zjawisk jak narodowa suwerenność i funkcjonowanie w ramach wielkiego bloku, centralne zarządzanie gospodarką i kontrola społeczna, wreszcie demokracja i socjalizm. Tylko katolicka lewica była w stanie - konstatowali publicyści „Za i Przeciw" - zapewnić poparcie dla przemian w społeczeństwie i nadać polskiemu socjalizmowi rys etyczny. Nie będąc marksistami, publicyści „Za i Przeciw” nie chcieli „socjalizmu wieloświatopoglądowego” ale „wieloświatopoglądowości demokratycznej”. Szeroki pluralizm w miejsce funkcjonowania totalnych obozów miał się wyrażać także w funkcjonowaniu rozdyskutowanego tygodnika lewicowej inteligencji ${ }^{73}$. Nadzieje Łubieńskiego, Morawskiej i ich kolegów na to, że ich pismo może stać się czynnikiem ożywiającym społeczeństwo, wkrótce okazały się płonne.

Procesy zakulisowe. Odejście „lewicy” i powołanie Chrześcijańskiego Stowarzyszenia Społecznego

We wrześniu, wobec możliwości rejestracji Stowarzyszenia (Frankowski zgodę uzyskał już w lipcu), „lewicowcy” doszli do wniosku, że powinno

73 A. Morawska, K. Łubieński, Cele i zadania, ZiP 1957, 23, s. 1, 5. 
ono nosić charakter zgodny z tym proponowanym w dyskusji programowej $^{74}$. Świadomie wyciągano w ten sposób rękę do redakcji „Po Prostu” i „Nowej Kultury”, co w oczach Gomułki musiało być już wówczas zabiegiem dyskwalifikującym. Rezygnacja przez grupę z szyldu „katolickiego” wywołała natomiast zadowolenie Episkopatu i Znaku. Uznano bowiem, że korzystniejsza jest mniejsza liczba organizacji katolików świeckich, ograniczy to bowiem władzom możliwość ich wygrywania przeciwko sobie $^{75}$. Zrozumiały był zdecydowany sprzeciw Frankowskiego wobec rozwoju sytuacji. Podstawą sporu były nie tylko różnice ideologiczne (Frankowski chciał, aby nowe ugrupowanie miało szyld i program deklaratywnie katolicki) i jego ambicje personalne (dążył do postawienia na czele nowej organizacji swoich ludzi), ale też, wyrażana przez Micewskiego czy Horodyńskiego, obawa przed przyjęciem przez nową organizację roli dywersyjnej wobec Episkopatu ${ }^{76}$. Konstatację tę potwierdzają wspomnienia Micewskiego - twierdził on, że programowa neutralność Frankowskiego w kwestii relacji państwo-Kościół była w oczach „lewicowców" powtórzeniem taktyki Piaseckiego. Innymi słowy (co zauważał Frankowski), liczono, że wobec możliwości konfrontacji Gomułki z prymasem Stefanem Wyszyńskim przyjęcie oblicza „lewicy bezpartyjnej” uchroni przed koniecznością dokonania kłopotliwych wyborów ${ }^{77}$. Chociaż u progu personalnej rozgrywki oceniano w Ministerstwie Spraw Wewnętrznych (MSW), że Frankowski z łatwością poradzi sobie z konkurentami, skompromitowanymi dostatecznie swą działalnością w ruchu Piaseckiego ${ }^{78}$, wypadki potoczyły się w bardziej skomplikowany sposób.

Dodać przy tym należy, że przyszły twórca ChSS już wcześniej niechętnie spoglądał na ideologiczne ambicje grupy „lewicy bezpartyjnej”, snując własne koncepcje organizacyjne ${ }^{79}$. Nie powiodły się próby zjednoczenia z chadekami (tych usilnie zwalczali Micewski, Kętrzyński i Horodyński) i Znakiem. Sam ruch „Za i Przeciw” już u swego zarania

74 AIPN, 0648/169/2, „Doniesienie” [źródło: „Górski”], 25 IX 1957, k. 103, 105.

75 AIPN, 0648/169/2, „Informacja wewnętrzna. Rozłam wśród członków grupy katolickiej «Za i Przeciw»", k. 66.

76 AAN, KC PZPR, V-52, Memoriał byłych redaktorów „Za i Przeciw” do Sekretariatu KC PZPR, 2 X 1957, k. 224; AIPN, 0648/169/2, „Doniesienie informacyjne” [źródło „Stefan”], 12 IX 1957, k. 81-82.

77 A. Micewski, Katolicy w potrzasku, s. 48-49.

78 AIPN, 0648/169/2, „Informacja wewnętrzna. Rozłam wśród członków grupy katolickiej «Za i Przeciw»", k. 67.

79 Potwierdzają to doniesienia agenturalne: AIPN, 0648/169/2 „Doniesienie agenturalne” [źródło: „Czechowski”], 2 III 1957, k. 29; ibidem, „Doniesienie” [źródło: „Czechowski”], 8 III 1957, k. 34; ibidem, „Doniesienie”, 6 VI 1957 [źródło: „Czechowski”], k. 59; ibidem, „Doniesienie” [źródło: „Górski”], 13 VI 1957, k. 60. 
dzielił się na grupę Frankowskiego (Dolański i Dziembowski), „właściwą secesję" (Łubieński, Horodyński, Kętrzyński, Micewski) oraz marginalizowanych i skłóconych wewnętrznie „niezależnych” (Kurowski, Wejroch, Romaniuk, Kłosiński). Pierwsi i drudzy nie byli ustosunkowani wrogo do ideologii Paxu, a jedynie do Piaseckiego. „Niezależni” natomiast całkowicie krytykowali Stowarzyszenie, podobnie jak „frondę”, z którą szczególne nadzieje wiązał Micewski ${ }^{80}$.

Pierwszym zewnętrznym objawem niesnasek był fakt, że tygodnik od numeru z 8 września 1957 r. podpisywany był w stopce przez bezosobowe kolegium z Instytutem Chrześcijańsko-Społecznym jako wydawcą. Świadczyło to o pozornej jedynie przewadze opozycji. W istocie Frankowski, dystansując się od redakcji, pozostawił swym konkurentom pismo bez zaplecza finansowego. Wycofał też podanie o rejestrację Związku Chrześcijańsko-Społecznego, nie chcąc, aby wpadł on w ręce Micewskiego, Kętrzyńskiego i ich kolegów ${ }^{81}$.

Do rozgrywki starano się wciągnąć samego Piaseckiego. Bliski zarówno liderowi Paxu, jak i Frankowskiemu Bocheński miał być łącznikiem pomiędzy nimi. Micewski próbował tymczasem pertraktować z Ryszardem Reiffem. Do Frankowskiego zgłosił się też Wiesław Chrzanowski, proponując, w zamian za pomoc w usunięciu „lewicy bezpartyjnej” i objęcie stanowiska redaktora naczelnego „Za i Przeciw”, poparcie inicjatywy Frankowskiego przez katolickie kluby Start i Dialog. Ponadto, obie grupy szukały pomocy w PZPR - Horodyński et consortes mogli liczyć na „młodych sekretarzy”, a jeszcze w ostatnich dniach września Artur Starewicz (szef Biura Prasy Komitetu Centralnego PZPR) i Jerzy Sztachelski (szef Urzędu do Spraw Wyznań) przekonywali ich o pozytywnym stosunku partii do ich ambicji. Frankowski natomiast mógł być pewny protekcji Zenona Kliszki ${ }^{82}$. Nie ma natomiast przekonujących dowodów na to, że realnie starano się pozyskać środowiska związane z Katolickim Uniwersytetem Lubelskim.

${ }^{80}$ AIPN, 0648/169/2, „Doniesienie informacyjne dot. środowiska skupionego wokół tygodnika «Za i Przeciw»” [źródło: „Stefan”], 5 VI 1957, k. 57-58; A. Micewski, Katolicy w potrzasku, s. 47-48.

81 AIPN, 0648/169/1, „Doniesienia informacyjne”, 18 IX 1957, k. 68-69; ibidem, „Notatka służbowa”, 18 IX 1957, k. 70-71; ibidem, „Notatka”, 20 IX 1957, k. 72; ZiP 1957, 25, s. 15. Zob.: A. Friszke, Opozycja polityczna, s. 193-194.

82 AAN, KC PZPR, V-52, Memoriał byłych redaktorów „Za i Przeciw” do Sekretariatu KC PZPR, 2 X 1957, k. 225; AIPN, 0648/169/2, „Informacja z rozmowy z Piaseckim”, 21 IX 1957, k. 73; ibidem, „Doniesienie informacyjne”, 25 IX 1957, k. 74-75; ibidem, „Doniesienie informacyjne”, 29 IX 1957, k. 87-89; ibidem, „Doniesienie”, 25 IX 1957, k. 103-104; Pót wieku polityki czyli Rzecz o obronie czynnej. Z Wiesławem Chrzanowskim rozmawiali Piotr Mirecki i Bogusław Kiernicki, Warszawa 1997, s. 246-247. 
Około 20 września sytuacja była wyjątkowo napięta. Micewski zarządził nocne dyżury w drukarni „Za i Przeciw”, w obawie przed przeniknięciem tam ludzi Frankowskiego, on sam zaś starał się zahamować wydawanie periodyku, a gdy to okazało się niemożliwe, ,przemycać” tam swoje artykuły. Grupa „lewicy” wystosowała 24 września do Frankowskiego memoriał, w którym, wobec rysującej się przegranej, starała się w korzystnym, złagodzonym świetle przedstawić swoje poglądy. Zirytowany Horodyński ${ }^{83}$ rozgłaszał opinie, że z racji żydowskiego pochodzenia Frankowski ${ }^{84}$ może liczyć na wsparcie w nowym kierownictwie partii ${ }^{85}$.

Sam Frankowski, w skierowanym do Antoniego Alstera memoriale, poddał druzgoczącej krytyce swych oponentów. Wybór adresata dokumentu dowodził znajomości, jakie Frankowski posiadał w kierownictwie PZPR, ale i orientacji w walkach frakcyjnych. Alster, ówczesny wiceminister spraw wewnętrznych, zajmujący się m.in. sprawami wyznaniowymi, był prominentnym członkiem frakcji puławian, w której protektora usiłowała szukać grupa „lewicy bezpartyjnej”. Frankowski nie lekceważył zatem zabiegów przeciwników. W rzeczonym dokumencie oceniał, że grupy katolików świeckich mogą istnieć pod warunkami akceptacji realiów ustrojowych i geopolitycznych, a konkretnie - przemian październikowych oraz posłuszeństwa Episkopatowi jedynie w kwestiach ściśle dogmatycznych. Innymi słowy, Znak i „Za i Przeciw” (Pax dowiódł, jego zdaniem, że jest czynnikiem generującym więcej problemów niż korzyści) są władzy potrzebne o tyle, o ile potrafią zmobilizować społeczeństwo do udzielenia jej poparcia. Oznaczało to jednak również, że z dezaprobatą należało traktować próby ich ideologicznej samodzielności, które mogły je poróżnić nie tylko z PZPR, ale i z hierarchią. Frankowski przestrzegał Alstera zwłaszcza przed sympatiami, jakie grupa „lewicy

${ }^{83}$ Horodyński był także przerażony, obawiał się aresztowania, a jeszcze bardziej zemsty dawnych kolegów z Paxu. J. Zabłocki, Dzienniki, s. 116.

${ }^{84}$ Ojciec Frankowskiego dokonał konwersji z judaizmu na katolicyzm, aby móc zawrzeć związek małżeński z katoliczką, matką przyszłego twórcy ChSS. Efektem była nagonka na niego ze strony lokalnej społeczności żydowskiej i emigracja. Sam Frankowski był na tyle przejęty w młodości wiarą katolicką, że pragnął wstąpić do seminarium duchownego. Spotkał się jednak z odmową odpowiednich władz kościelnych z powodu swego pochodzenia. AIPN, 00231/231/2, „Notatka służbowa”, 23 VII 1967, k. 5-6; ibidem, „Notatka”, 24 VII 1967, k. 7.

${ }^{85}$ AAN, KC PZPR, 237/XIX-170, List publicystów „Za i Przeciw” do Jana Frankowskiego, 24 IX 1957, k. 20-22; ibidem, UdSW, 74/82, Anonimowa informacja o sytuacji w „Za i Przeciw”, 26 IX 1957, k. 231; AIPN, 0648/169/2, „Doniesienia informacyjne” [źródło: „Górski”], 26 IX 1957, k. 76-78; ibidem, List Jana Frankowskiego do Dominika Horodyńskiego, 24 IX 1957, k. 79-80; ibidem, „Doniesienie” [źródło: „Górski”], 25 IX 1957, k. 103-104. 
bezpartyjnej” wyrażała wobec prasy „rewizjonistycznej” i przekonywał go, że jeśli partia nie pomoże mu w walce z konkurentami, to w dobie „racjonalizacji odwilży” (jak eufemistycznie określał odejście od tendencji Października) stworzy środowisko równie groźne jak „Po Prostu”"86. Z pewnością był to dobry argument - w „Za i Przeciw” publikował wszak Kurowski, którego artykuły w najgłośniejszym piśmie polskiej „odwilży” krytykowało bardzo mocno Biuro Prasy $\mathrm{KC}^{87}$.

W memoriale Frankowski wspominał też, że przed katolickimi „rewizjonistami” przestrzegał Kliszkę. Zdaniem Micewskiego, udało mu się ostatecznie przekonać prawą rękę Gomułki o radykalnym „rewizjonizmie" "lewicy” za pomocą wyrwanych z kontekstu fragmentów ich artykułów. Jeśli tak, świadomie wprowadził go w błąd - granicą radykalizmu było dla „bezpartyjnych” utrzymanie zdobyczy Października. Jak się jednak wydaje, argumentacja Frankowskiego odniosła skutek także dzięki zadeklarowaniu pozytywnego stosunku do ustroju opartego nie tylko na realizmie, z powodu braku zaufania decydentów do niedawnych ideologów Paxu, a przede wszystkim - dzięki przekonaniu, że Frankowski dąży do utworzenia kolejnego, obok grup Piaseckiego i Znaku, środowiska katolików świeckich, co było ze wszech miar korzystne dla władzy, zgodnie z zasadą divide et impera ${ }^{88}$.

Było to zgodne z wytycznymi Biura Politycznego KC PZPR w kwestiach polityki wobec środowisk katolików świeckich z czerwca 1957 r. Uznano w nich, że wobec fiaska koncepcji autentycznego przekonania katolików do ideologii marksistowskiej za pomocą Paxu, należy przede wszystkim dążyć do ich lojalnego i pozytywnego stosunku do państwa, wskazując na korzyści, jakie mogą dzięki temu odnieść. Było to zadaniem dla środowisk takich jak Znak czy grupa „Za i Przeciw”. Wymogami wobec nich był autentyczny światopogląd katolicki przy nieporuszaniu kwestii stricte teologicznych i niechęć do tworzenia organizacji masowej. W tym kontekście rozpatrywano Pax jako dość „zgrany” w społeczeństwie, ale posiadający znaczny potencjał. Znak był niejednorodny, a grupa Frankowskiego nieliczna. $Z$ tą ostatnią wiązano jednak spore nadzieje, proponując udzielenie jej ostatecznie zgody na utworzenie niewielkiej

${ }^{86}$ AIPN, 0648/169/2, Memoriał Jana Frankowskiego do Antoniego Alstera, 1957, k. 91-102. Tekst memoriału także w: AAN, UdsW, 129/5, k. 35-46.

87 AAN, KC PZPR, 237/XIX-234, „Wyjątki z skonfiskowanego prowokacyjnego numeru «Po Prostu»”, k. 24-26; ibidem, „W sprawie likwidacji tygodnika «Po Prostu»”, X 1957, k. 40-41. Grupa lewicy bezpartyjnej odcinała się jednoznacznie od Kurowskiego i w ogóle od „rewizjonizmu”, ibidem, V-52, Memoriał byłych redaktorów „Za i Przeciw” do Sekretariatu KC PZPR, 2 X 1957, k. 227-228.

${ }^{88}$ A. Micewski, Katolicy w potrzasku, s. 48-49. 
organizacji, a także proponując wspólne ze Znakiem wydawanie dziennika katolickiego, a w celu zwiększenia popularności, nakłaniając ją do współpracy z „frondą" lub klubem Dialog. Znamienne, że komuniści nie wypowiedzieli się w sprawie dyskusji ideologicznej na łamach „Za i Przeciw”. „Wytyczne stanowiska partii w sprawie stosunków między państwem a kościołem" były jednak zgodne z ograniczonym programem Frankowskiego, oznaczając zasadę niewspierania „jednolitości środowiska katolickiego" i nielikwidowania grup lojalistycznych ${ }^{89}$.

Przesilenie nastąpiło u schyłku miesiąca, co wiązać też można z zamknięciem tygodnika „Po Prostu”, na współpracę z którym liczyli „lewicowcy”. Sprawę mogło przesądzić odrzucenie przez redakcję artykułu Frankowskiego W sprawie naszego programu, co KC PZPR traktowało jako miernik rzeczywistej postawy „Za i Przeciw”. Zaborski twierdził 29 września, że zwycięstwo Frankowskiego jest przesądzone, tak wobec spadku znaczenia „wściekłych” („rewizjonistów”) w partii, jak i protekcji Piaseckiego, jaką jego konkurent miał uzyskać (jak się wydaje, była to nadinterpretacja, szef Paxu liczył raczej, że spory w secesji pozwolą na jej ostateczne rozbicie i powrót ludzi Frankowskiego pod jego skrzydła). Już dzień wcześniej do czołowych opozycjonistów Frankowski wysłał listy $\mathrm{z}$ informacją o przejęciu redakcji tygodnika. Istotnie, mimo ich oburzenia, porównującego całą akcję z przejęciem „Tygodnika Powszechnego" przez Pax w 1953 r., koncepcja „lewicy bezpartyjnej” poniosła sromotną porażkę ${ }^{90}$.

Jak się wydaje, wobec wsparcia Kliszki, i, co za tym idzie, samego Gomułki, a także faktu, że „lewica bezpartyjna” nie zdołała pozyskać i tak tracących już na znaczeniu puławian (być może obawiali się oni wiązania się z inicjatywą o otwarcie „rewizjonistycznym” charakterze), zwycięstwo Frankowskiego było nieuchronne. Micewski i jego współpracownicy usiłowali jeszcze bezskutecznie uzyskać od partii zgodę na odebranie Frankowskiemu spółki Ars Christiana. Łubieńskiemu udało spotkać się z Zambrowskim oraz przekazać memoriał do Sekretariatu KC. Był on jednak, w optyce Gomułki, potwierdzeniem jego podejrzeń. Odrzucano w nim jednoznacznie opcję lojalistycznego obozu katolickiego, broniąc koncepcji jedynie inspirowanej chrystianizmem niemarksistowskiej

89 AAN, KC PZPR, V-52, „Wytyczne stanowiska partii w sprawie stosunków między państwem a kościołem", k. 285-291; A. Friszke, Kościół a państwo realnego socjalizmu, „Więź” 1997, 3, s. 146-151; idem, Nadzieje i złudzenia, s. 108-111. Por. AAN, UdsW, 74/77, J. Krasnowolski, „Zasadnicze założenia katolickiego ruchu społecznie-postępowego”, 7 V 1957, k. 130.

90 AIPN, 0648/169/2, „Doniesienie informacyjne” [źródło: „Stefan”], 29 IX 1957, k. 87-89; A. Micewski, Katolicy w potrzasku, s. 49. 
lewicy bezpartyjnej ${ }^{91}$. Nie może dziwić, że ani Gomułka, ani Kliszko nie byli już zainteresowani kontaktem z przeciwnikami Frankowskiego. Podobnie jałowe było kolportowanie pogłosek o sterowaniu Frankowskim przez Piaseckiego, o czym świadczyć miało powierzenie Bocheńskiemu stanowiska zastępcy redaktora naczelnego „Za i Przeciw”. Jego uczestnictwo w secesji wynikało z początkowej niewiary w szanse przetrwania Paxu. Potem nie spełniał on roli agenta Piaseckiego w „Za i Przeciw”, ale pośrednika w roboczych kontaktach. Bocheński zresztą nie opublikował w tym czasie żadnego artykułu na łamach pisma, wkrótce wracając pod skrzydła dawnego wodza Falangi ${ }^{92}$. Po niedługim czasie sam Micewski zaczął przemyśliwać o ponownym przyłączeniu się do Paxu. Liderzy opozycji, wyrzuceni z redakcji, szukać musieli nowych dróg działania. Oprócz nich grupę opuścili Kurowski, Zaborski, Wejroch i Sachs. Po przejęciu redakcji przy Frankowskim z działaczy dużej miary pozostali: Bocheński, Zygmunt Filipowicz, Meysztowicz, Dolański i Janusz Makowski ${ }^{93}$. W ten sposób, jak konstatowano w donosie z 3 października, ,zakończył się «październik» w "Za i Przeciw»" 94 . W stopce 29 numeru tygodnika Frankowski podpisał już pismo „Za Wydawnictwo i Redakcję” (dzięki odebraniu koncesji na wydawanie kolegium) ${ }^{95}$.

Nie bez satysfakcji komentowano za to w Paxie, że Frankowski „bandę łobuzów” (czyli Łubieńskiego etc.) potraktował tak, jak wcześniej oni Piaseckiego, chociaż dodawano, że „największym” z łobuzów był nieprzebierający w środkach redaktor „Za i Przeciw” ". Zastępca Piaseckiego, Jerzy Hagmajer, złośliwie stwierdził, że nie wiedział, iż przez dekadę miał do czynienia z takimi politycznymi głupcami jak Micewski

91 AAN, KC PZPR, V-52, Pismo Konstantego Łubieńskiego do Władysława Gomułki, 4 X 1957, k. 219; ibidem, Memoriał byłych redaktorów „Za i Przeciw” do Sekretariatu KC PZPR, 2 X 1957, k. 220-230; ibidem, 237/XIX-170, Pismo Dominika Horodyńskiego i Konstantego Łubieńskiego do Artura Starewicza, 5 X 1957, k. 1.

92 O działalności Micewskiego i Bocheńskiego zob.: AIPN, 0648/169/2, „Informacja dot. Micewskiego i spółki”, 4 X 1957, k. 116; ibidem, „Notatka z odbytego spotkania z inf. ps. «Czechowski»”, 7 X 1957, k. 120; ibidem, „Informacja dot. działalności części grupy «Za i Przeciw» kontra Frankowski J.” [źródło: „Blondyn”], k. 106-107; ibidem, „Informacja” [źródło: „Blondyn”], 10 X 1957, k. 122.

93 AIPN, 0648/169/1, „Lista założycieli Stowarzyszenia pod nazwą Chrześcijański Związek Społeczny”, k. 8; ibidem, „Lista uczestników Zjazdu Chrześcijańskiego Stowarzyszenia Społecznego", k. 24-28.

94 AIPN, 0648/169/2, „Doniesienie” [źródło: „Górski”], 3 X 1957, k. 112-114. Rozłam w „Za i Przeciw” „Tygodnik Powszechny” odnotował jedynie suchą wzmianką kronikarską.

95 ZiP 1957, 29, s. 15; A. Friszke, Nadzieje i złudzenia, s. 110-111, 113.

96 AIPN, 0648/169/2, Stenogram z podsłuchanej rozmowy telefonicznej, 3 X 1957, k. $115-116$. 
czy Horodyński - ich, wieloletnich ideologów „Dziś i Jutro”, wykończył „słabiutki adwokacik prowincjonalny” Frankowski. Schadenfreude Piaseckiego i jego ludzi wynikała oczywiście z przekonania, że został wyeliminowany ich najgroźniejszy, obok Znaku, konkurent wśród polskich środowisk katolików świeckich ${ }^{97}$.

6 października ukazał się zatrzymany wcześniej artykuł $W$ sprawie naszego programu. Frankowski stwierdzał w nim, że w ostatnim czasie dyskusja programowa zaczęła odchodzić od tez wskazanych we wstępnej deklaracji, kierując się na swoiste bezdroża. Tymczasem, istnienie takiej grupy politycznej jak „Za i Przeciw” (jak i każdej innej w warunkach polskich) było uzasadnione tylko wówczas, jeśli wpisywała się ona w program jednoczenia społeczeństwa pod hasłem podstawowych założeń racji stanu, jednocześnie nie dublując programu już istniejących. Bezpodstawnie zarzucał swym oponentom, że za mało pisali o „budownictwie ustrojowym państwa" czy pozytywnych skutkach sojuszu polsko-sowieckiego oraz że nie odróżniali się od Paxu czy Znaku. Za bałamutne należy uznać też zarzuty, jakoby zwolennicy hasła „lewicy bezpartyjnej” głosili brak zainteresowania stanem relacji państwo-Kościół czy wysuwali koncepcje, których realizacja, na skutek swego radykalizmu, mogła narazić sam dorobek Października. Jak wyżej podkreślono, czołowi publicyści grupy wielokrotnie przestrzegali przed formułowaniem zbyt daleko idących postulatów politycznych czy ekonomicznych. Niemniej jednak, „lewicowcy” rzeczywiście traktowali chrystianizm jedynie jako inspirację etyczną, wbrew koncepcji Frankowskiego. Poważniejszym politycznie zarzutem, który istotnie znajdował potwierdzenie w tekstach „bezpartyjnych", było oskarżenie o wywodzenie pozytywnego stosunku do PRL jedynie z pragmatycznej oceny sytuacji, z wyraźną granicą kompromisu. Ponadto, demokratyzacja, dowodził Frankowski, musiała też oznaczać socjalizm, a nie tylko lewicowość, opierającą się na środowiskach niemarksistowskich i niekatolickich. Grupa „Za i Przeciw” miała być zatem „popaździernikowym ugrupowaniem ideowo-politycznym”, stojącym na gruncie katolickim i marksistowskim, co zresztą niebezpiecznie zbliżało tę koncepcję do paksowskiej „wieloświatopoglądowości socjalizmu”. Z pewnością zaś, w optyce Frankowskiego, katolicy świeccy powinni być nie chłodnymi realistami czy twórcami polskiej „, nowej lewicy” (na wzór francuski), lecz wiernymi doktrynie Kościoła patriotami Polski Ludowej. W istocie też, różniąc się od ruchu Piaseckiego w stosunku do przemian październikowych, akceptował on jego wizję pozycji Kościoła i laikatu

97 AIPN, 0648/169/2, „Notatka z odbytego spotkania z inf. ps. «Kowalski»”, 9 X 1957, k. 121. 
w państwie oraz jej filozoficzne podstawy. Formułując nawiązujące do cnót chrześcijańskich i patriotyzmu postulaty, Frankowski dawał wyraz zdolności do głoszenia górnolotnych haseł, w istocie jednak jego refleksja spychała jego własne środowisko polityczne do roli „odwilżowego" skrzydła Paxu. Była też symptomem generalnego odwrotu polskiej publicystyki od śmiałej refleksji politycznej. Znamienne, że Frankowski, który z Piaseckim rozstał się m.in. na skutek zarzutów o tłamszenie wewnętrznej debaty i usprawiedliwianie tego oportunistycznym realizmem, przejmując władzę w tygodniku, dokonywał analogicznego czynu ${ }^{98}$.

Od tego momentu „Za i Przeciw” jedynie ogólnikowo pisało o „problemach codziennych", we wszystkich kwestiach istotnych opowiadając się jednoznacznie za linią władzy (jak w kontekście protestów młodego pokolenia z jesieni 1957 r.) ${ }^{99}$. Sam Frankowski wyrażał „urzędowy optymizm", bagatelizując społeczne niezadowolenie jako dowód deficytu realizmu u swych rodaków. Jego zdaniem, rok po wydarzeniach październikowych dorobek nowej ekipy w kontekście spraw kluczowych oceniać należało zdecydowanie in plus. Brakowało w jego rozważaniach tak charakterystycznych dla dyskusji ideologicznej refleksji nad sensem kolejnych reform czy programem działania katolików świeckich. Frankowski wyrażał poglądy tych, którzy przemiany ograniczali do usprawnienia gospodarki i przywrócenia pewnych praw Kościoła. Nie było w tym wypadku miejsca na pluralizm ideowy. Powodem do optymizmu była świadomość osiągnięcia maksimum możliwych korzyści - w sensie geopolitycznym od 1945 r., w sensie wewnątrzpolitycznym od $1956^{100}$. Jakże inna była postawa „Tygodnika Powszechnego”, który z okazji rocznicy Października pisał wprost o tym, że jest on zagrożony przez tych, którzy chcą nawrotu do dawnych metod rządzenia ${ }^{101}$.

Konsekwencją takiej linii politycznej było utworzenie organizacji stojącej na gruncie wysoce afirmatywnym wobec rzeczywistości politycznej PRL. 18 października w Warszawie, dzięki zatwierdzeniu wniosku i projektu statutu opracowanego przez nową redakcję „Za i Przeciw”, odbyło się pierwsze zebranie członków nielicznego Chrześcijańskiego Stowarzyszenia Społecznego. Frankowski został wybrany jego prezesem, Dziembowski, jeden z niewielu pozostałych przy nim członków „starego" zespołu, wiceprezesem, sekretarzem Filipowicz, Meysztowicz zaś

98 J. Frankowski, W sprawie naszego programu, ZiP 1957, 29, s. 1-2.

99 O. Czerniewicz, Refleksje postrajkowe, ZiP 1957, 29, s. 13; Z.K. Nowakowski, Dobrze zrobiono ale można lepiej - kilka uwag o własności lokali, ZiP 1957, 30, s. 1; J. Frankowski, Gospodarskie oko, ZiP 1957, 31, s. 1-2.

100 J. Frankowski, Uzasadniony optymizm, ZiP 1957, 32, s. 1-2.

101 Rocznica, TP 1957, 41, s. 1. 
członkiem zarządu. W uchwalonej rezolucji głoszono afirmację przemian październikowych, wzywając obywateli do dalszej troski o demokratyzację poprzez rzetelne wykonywanie swoich obowiązków w oparciu o etykę chrześcijańską (było to w zasadzie jedyne nawiązanie do kwestii wyznaniowych). Uznając za swoiste wytyczne artykuł Frankowskiego $W$ sprawie naszego programu, ChSS zgłaszało bezwarunkowy akces do Frontu Jedności Narodu (FJN). Na łamach periodyku nie wspomniano oczywiście o wcześniejszych politycznych sporach i koncepcjach. Od numeru 37 był też Frankowski redaktorem naczelnym tygodnika (od numeru 39 wydawanego formalnie przez ChSS) ${ }^{102}$, który zresztą ewidentnie tracił na popularności, zwracając się do swych czytelników o pomoc w kolportażu i upowszechnianiu ${ }^{103}$. Bazą finansową ChSS była Ars Christiana, zwrócona Caritasowi (Frankowski pozostawał jego wiceprezesem), który następnie odsprzedał ją Stowarzyszeniu. Dzięki połączeniu tego manewru z rozwiązaniem Instytutu Chrześcijańsko-Społecznego swoje udziały w nim stracili Horodyński i inni. Jeszcze w listopadzie ci ostatni odgrażali się, że wszelkimi środkami będą dążyli do zniszczenia „Za i Przeciw” (wyjątkiem był Łubieński, który związał się już w tym czasie ze Znakiem). Nasuwać się muszą w tym wypadku analogie z sytuacją z listopada 1956 r., kiedy „secesjoniści” spodziewali się, że uda im się przejąć Pax w momencie, gdy Piasecki triumfował już w walce o pozycję w Stowarzyszeniu ${ }^{104}$.

\section{Epilog}

Kilka słów poświęcić jeszcze należy dalszym politycznym losom głównych bohaterów niniejszego tekstu. Łubieński wkrótce stał się jednym

102 ZiP 1957, 37, s. 14; 39, s. 14.

103 AAN, UdSW, 74/82, Uchwały podjęte na zebraniu organizacyjnym ChSS, k. 255; Do naszych czytelników, ZiP 1957, 35, s. 11. Początkowo zwracano niemal 80 proc. nakładu, jednak już w 1959 r. wskaźnik ten spadł do 25 proc., a pod koniec 1960 r. poniżej 10 proc. AAN, KC PZPR, 237/XIX-170, „Informacja o prasie katolickiej”, b.pag.; ibidem, „Zestawienie nakładów wyd. katolickich”, 1957, k. 63; ibidem, „Nakłady prasy katolickiej”, 1959, k. 160-161; ibidem, UdsW, 74/74, Pismo do Zenona Kliszki, 16 I 1961, k. 9.

104 AAN, UdsW, 129/72, „Informacja w sprawie Zrzeszenia Katolików «Caritas»”, k. 136; ibidem,129/17, Skład Zarządu Głównego Caritas, k. 1; ibidem, Korespondencja w sprawie sprzedaży Ars Christiana, III-IV 1958, k. 311-320; ibidem, ARR, 255, Pismo prezesa ZG ZK Caritas ks. A. Lempartego do prezesa ChSS J. Frankowskiego, 19 III 1959, b.pag.; AIPN, 0648/169/1, Informacja nt. władz ChSS, k. 7; ibidem, Informacja w sprawie rejestracji ChSS, k. 127; ibidem, 0648/169/2, „Doniesienie” [źródło: „Górski”], XI 1957, k. 128-130; ibidem, „Doniesienie” [źródło: „Kwiatkowski”], 19 XI 1957, k. 131; Chrześcijańskie Stowarzyszenie Społeczne, ZiP 1957, 32, s. 5. 
z czołowych działaczy ruchu Znak i jego sztandarowym ekonomistą. W liście do „Tygodnika Powszechnego" pisał, że chociaż jest przeciwny „ugrupowaniom politycznym o charakterze wyznaniowym”, to dostrzegając konieczność publicznego zaangażowania katolików, najpełniejsze jego możliwości widzi w środowisku Znaku. Zaznaczał przy tym swoją polityczną autonomię, zgodną ponoć z zasadą, według której katolicyzm nie jest tożsamy z określoną doktryną polityczną. Chociaż jeszcze w $1968 \mathrm{r}$. był zdecydowanym zwolennikiem wzięcia w obronę przez koło poselskie represjonowanych studentów, z czasem stał się rzecznikiem ugodowego kursu w sporze między Zabłockim a Stommą, opowiadając się za tym pierwszym i przyczyniając się do rozłamu w ruchu. Doprowadziło go to do funkcji wiceprzewodniczącego Ogólnopolskiego Komitetu FJN i członka Rady Państwa ${ }^{105}$. Horodyński po 1957 r. jako publicysta zajął się głównie problematyką międzynarodową, będąc korespondentem prasowym w Rzymie, a w latach 1970-1981 pełniąc funkcję redaktora naczelnego warszawskiej „Kultury”"106. Kętrzyński, po służbie dyplomatycznej (konsul generalny w Montrealu, przedstawiciel Polski w UNESCO, radca ambasady w Paryżu), związał się w połowie lat siedemdziesiątych z ChSS (wchodził w skład jego zarządu) oraz jego prasą ${ }^{107}$. Micewski zbliżył się do środowiska Znaku poprzez „Więź” i Kluby Inteligencji Katolickiej. W „Więzi”, którą od neopozytywistycznego „Tygodnika Powszechnego” odróżniała większa skłonność do refleksji ideowej i nieskrywane poparcie dla radykalnych, lecz niemarksistowskich koncepcji społeczno-ekonomicznych ${ }^{108}$, mógł odnaleźć środowisko częściowo bliskie jego poglądom z lat 1956$1957^{109}$. Warto dodać, że w 1957 r. usiłował, w sposób dość impertynencki, przekonywać Stommę do rozszerzenia bazy politycznej Znaku o element „młodolewicowy”, argumentując, że sprawa „lewicy bezpartyjnej” nie jest jeszcze przegrana ${ }^{110}$. Zajmował się przede wszystkim publicystyką historyczną, w latach osiemdziesiątych zaś był jednym z doradców prymasa Józefa Glempa. Ostatnim epizodem jego kariery politycznej był,

105 Wyjaśnienie posła K. Łubieńskiego, TP 1957, 49, s. 7.

106 A. Friszke, Między wojna..., s. 388.

107 Nowe władze Chrześcijańskiego Stowarzyszenia Społecznego, ZiP 1977, 23, s. 3; W. Kętrzyński, Wybór własnych dróg, ZiP 1977, 24, s. 4; P. Kardela, op. cit., s. 160-180.

108 Dyskusja o roli Klubów Inteligencji Katolickiej, „Więź” 1963, 1, s. 5-27; Trzydzieści lat „Więzi” [rozmowa Wojciecha Wieczorka z Andrzejem Friszke], „Więź” 1988, 2, s. 3-24.

109 Por. jego późniejszą refleksję: A. Micewski, Uwagi o odwadze myślenia w polityce, „Więźz" 1968, 5, s. 38-47.

110 AAN, Archiwum Stanisława Stommy, 4.2/220, List Andrzeja Micewskiego do Stanisława Stommy, 5 XII 1957, b.pag. Por. informację o nieskładaniu broni przez Micewskiego: AAN, UdsW, 148/1, „Biuletyn Informacyjny Urzędu do spraw Wyznań” 1959, 9, k. 179-180. 
już w III RP, mandat posła na sejm II kadencji z list Polskiego Stronnictwa Ludowego ${ }^{111}$. Wszyscy czterej byli działaczami o wielkich ambicjach, przez co z trudem odnajdywali się w miejscach, gdzie nie mogli być liderami. Bocheński natomiast, jak już wspomniałem, związał się po tych wydarzeniach z Paxem, gdzie jednak uchodził za ideowego outsidera ${ }^{112}$.

Najciekawsze były jednak losy Frankowskiego - tworząc ChSS, świadomie ograniczył ideowe i polityczne ambicje stowarzyszenia ${ }^{113}$. Skutki tego dla ruchu, który miał być w założeniu nową jakością w środowiskach polskich katolików świeckich, były katastrofalne. Pomijając fakt, że on sam ograniczał początkowo liczebność grupy do kilkudziesięciu osób, obawiając się, że nie zapanuje nad większym gronem, większość członków ChSS i tak nie przejawiała większego zainteresowania jego działalnością. Jak stwierdzano w MSW, miałkość ideowa doprowadziła do bankructwa wszelkich form pracy poza wydawaniem „Za i Przeciw”, które starało się lawirować pomiędzy Episkopatem a władzami. Spotkania i kluby dyskusyjne ChSS nie cieszyły się popularnością, nie udało się utworzyć lokalnych kół, Frankowski stracił popularność nawet na bliskiej mu Kielecczyźnie, nie zdołał też pozyskać środowiska Katolickiego Uniwersytetu Lubelskiego ${ }^{114}$. Źle wyglądała także materialna sfera działalności stowarzyszenia - Ars Christiana była początkowo nierentowna i źle zarządzana, a do „Za i Przeciw” trzeba było dopłacać. Stąd też nie może dziwić konstatacja funkcjonariusza Służby Bezpieczeństwa, według którego "ChSs było i jest nadal całkowicie izolowane od wpływu na zagadnienia katolickie. Nie ma żadnych związków i stosunków z hierarchią, w stosunku do innych organizacji katolickich zajmuje pozycję zbrojnej neutralności, a oddziaływanie na katolików jest znikome, prawie żadne"115. W innym miejscu zauważano, że koncepcja Frankowskiego jest nierealna,

111 A. Friszke, Między wojna..., s. 388; A. Micewski, Katolicy w potrzasku, s. 49-50; idem, Dziennik idacego samotnie (czerwiec 1993 - wrzesień 1998), Warszawa 1998, s. 95-97.

112 Głównie ze względu na swój niepopularny realizm historyczny i niechęć do koncepcji „wieloświatopoglądowości”.

${ }^{113}$ J. Frankowski, Treść naszej pracy, ZiP 1958, 42, s. 2; idem, Setny numer to znaczy dobry, ZiP 1959, nr 7, s. 1; idem, Krzyż - atom - ludzkość, ZiP 1959, 12, s. 1-2.

114 AAN, UdSW, 74/92, Informacja Wojewódzkiej Rady Narodowej w Kielcach w sprawie prób organizacji oddziału ChSS, 5 II 1958, k. 291; AIPN, 0648/169/2, „Doniesienie agenturalne” [źródło: „Górski”], 29 XI 1957, k. 132-135; ibidem, „Doniesienie” [źródło: „Górski”], 7 XII 1957, k. 136-140.

115 AIPN, 0648/169/1, „Informacja dot. wyborczego zjazdu ChSS”, 1 XII 1959, k. 3031. Por. AAN, UdsW, 129/12, Charakterystyka Jana Frankowskiego, k. 46; ibidem, Akta Jana Frankowskiego (dalej: AJF), 5, List Janusza Makowskiego do biskupa katowickiego Herberta Bednorza dot. szykan kleru wobec członków ChSS, 13 VI 1965, b.pag. Sekretarz Episkopatu, biskup Zygmunt Choromański, spotkanie z kierownictwem ChSS uznawał za „bezcelowe”, ibidem, Notatka z dwóch rozmów z biskupem Choromańskim, b.pag. 
także z powodu braku dalekosiężnej strategii. Przywódcy ChSS nie cieszyli się popularnością wśród polskich intelektualistów, brak im też było (poza Frankowskim) zdolności politycznych. Organizacja była zatem przydatna dla systemu politycznego Polski Ludowej jako łatwa do sterowania, jednocześnie jednak możliwości jej praktycznego wykorzystania $\mathrm{w}$ rozgrywce $\mathrm{z}$ Episkopatem były niewielkie ${ }^{116}$. Władze starały się więc umocnić ChSS, projektując jego połączenie z „Więzią”, starając się też skłonić Frankowskiego do większej aktywności. Chociaż komunistów cieszyła lojalność ugrupowania, to równocześnie zdawali sobie sprawę z jego niewielkiej użyteczności. Jak się wydaje, z czasem zaczęła ich też irytować hegemoniczna pozycja Frankowskiego, który nie potrafił spełnić pokładanych w nim nadziei ${ }^{117}$. Znamienne, że Pax, chociaż spotykał się z ostrą krytyką Gomułki za swoją linię, był uznawany za organizację pożyteczną ${ }^{118}$. ChSS był bezproblemowy, ale i, w optyce partii, niepożyteczny.

Oczywiście, nie jest możliwa precyzyjna odpowiedź na pytanie, czy gdyby środowisko „Za i Przeciw” przyjęło linię postulowaną przez Micewskiego, Kętrzyńskiego i Łubieńskiego, zyskałoby większą popularność. W świetle powyższych faktów jednak jest ono co najmniej zasadne. Last but not least, model organizacyjny i ideowy, jaki narzucił ChSS Frankowski, sprzyjał zyskaniu i utrzymaniu przez niego przywództwa. W MSW i Urzędzie do spraw Wyznań po kilku latach od opisywanych wydarzeń konstatowano charakterystyczny „minimalizm” ChSS i jego lidera. Czuł się on dobrze jako parlamentarzysta, działacz ekonomiczny czy społeczny, ale nie jako lider poważnego ugrupowania. $Z$ tego powodu miał zaprzepaścić pewne perspektywy dla swej organizacji, pewny mógł być za to w nim swej pozycji119. Dodać jednak należy, że trudno było spodziewać się, aby dawny „odrodzeniowiec” i faktyczny twórca „Za i Przeciw” zgodził się

116 AIPN, 0648/169/1 „Informacja dot. działalności Chrześcijańskiego Stowarzyszenia Społecznego za 1958 r.”, 1 III 1959, k. 49-53; ibidem, „Tezy”, 31 III 1959, k. 55; ibidem, „Załącznik do informacji o działalności ChSS”, k. 76-78.

117 AAN, UdsW, 74/82, Notatka Jerzego Sztachelskiego do Zenona Kliszki z rozmowy przeprowadzonej z Janem Frankowskim, 7 V 1957, k. 305-306; ibidem, 129/5, „Informacja dotycząca działalności Chrześcijańskiego Stowarzyszenia Społecznego", k. 6-12; ibidem, „Notatka dot. Chrześcijańskiego Stowarzyszenia Społecznego”, k. 27-29; ibidem, 129/6, Wytyczne Wydziału Administracyjnego KC PZPR w sprawie grup katolickich, II 1961, k. 3; ibidem, „Informacja dotycząca działalności ugrupowania katolickiego «Więź»”, III 1961, k. 98-99; ibidem, 129/72, „Charakterystyka aktualnej działalności stowarzyszeń katolickich", I 1965, k. 182.

118 AAN, UdsW, 129/11, Zapis rozmowy Władysława Gomułki, Zenona Kliszki, Ryszarda Strzeleckiego i Jerzego Sztachelskiego z Bolesławem Piaseckim, Jerzym Hagmajerem i Ryszardem Reiffem, 1961, k. 1-14.

119 AAN, UdsW, 144/11, „Działalność Urzędu do spraw Wyznań w 1961 r.”, k. 14, 55; AIPN, 0648/169/1, Opracowanie nt. ChSS, k. 199. 
na przekazanie swego dzieła wyznawcom koncepcji, które uznawał za szkodliwe jako niekatolickie. Sam „lewicowość” rozumiał jedynie jako afirmację pojałtańskiej rzeczywistości, nie zaś snucie własnych, w jego mniemaniu radykalnych społecznie koncepcji (co sam czynił przed wojną). Za konieczne uznawał tylko tolerowanie przez władze działalności konfesyjnej Kościoła. Stąd też kierowane przez niego „Za i Przeciw” nosiło charakter tyleż wyznaniowy, co propagandowy ${ }^{120}$.

Czy był to „minimalizm” w słynnym ujęciu Stommy, czyli dostosowujący metody działania do rzeczywistości, ale nierezygnujący z imponderabiliów i zasadniczych celów? Jak wyżej zaznaczyłem, Frankowski doprowadził do rozłamu w „Za i Przeciw” w 1957 r. zarówno z powodu różnic ideologicznych, jak i oceny możliwości działania grupy „lewicy bezpartyjnej”. Odnieść można jednak wrażenie, że niezbyt ubolewał nad tym, iż porzucić musiał swoje przedwojenne, ambitne koncepcje (gdyby chciał je realizować, byłby wszak niemalże wzorcowym „maksymalistą”), co więcej, jako prezes ChSS czuł się w Polsce Gomułki dość komfortowo. Jego taktyka nie polegała na przeczekaniu, nie chciał też, w dalszej perspektywie, przygotować gruntu do zwycięskiej rywalizacji z komunistami. Jak sam niejednokrotnie pisał, pragnął, aby katolicy polscy poparli socjalizm nie tylko ze względów rozumowych, ale i emocjonalnych. Jego „minimalizm" coraz częściej stawał się zwyczajnym oportunizmem. Trudno co prawda w pełni zgodzić się z opinią Micewskiego, że Frankowski był „konformistą bezideowym”, traktującym politykę jedynie w kategoriach biznesu (czy z jeszcze ostrzejszymi sformułowaniami Zabłockiego i Kisielewskiego, zarzucającymi mu wprost oportunizm i karierowiczostwo), przyznać należy jednak rację konstatacji, że nie wykazywał się on wielką ambicją, za to sporą zręcznością polityczną ${ }^{121}$.

Nie oznacza to bynajmniej, że Frankowski nie prowadził w latach sześćdziesiątych jakiejkolwiek gry politycznej. Starał się zyskać aprobatę Wyszyńskiego oraz, bliskich Gomułce, przeciwników gen. Mieczysława Moczara, sprzeciwiał się narastającym tendencjom antysemickim, sondował też możliwości współpracy z Paxem (Piasecki nie był do niego nieprzychylnie nastawiony ${ }^{122}$ ) i Znakiem (dzięki protekcji Kliszki, z którym

120 AIPN, 0648/169/2, „Doniesienie” [źródło: „Górski”], 15 X 1957, k. 125-126.

121 A. Micewski, Katolicy w potrzasku, s. 47-51; idem, Dziennik idacego samotnie, s. 123; J. Zabłocki, Dzienniki, s. 72-73; Kisiel [S. Kisielewski], Remanent świateczny czyli świat na nogach (felieton z makiem, pieprzem i wazelina), TP 1956, 1, s. 8.

122 Potwierdza to podsłuchana rozmowa w gabinecie szefa Paxu. Łącznikiem pomiędzy liderami obu ugrupowań był, co nie może absolutnie dziwić, Bocheński. AIPN, 0648/55/1 [materiały z podsłuchu w siedzibie Stowarzyszenia „Pax”], „Notatka służbowa dnia 3 III 1961 r.", 4 III 1961, k. 176-178. 
negocjował samowolnie kwestie dotyczące „Więzi”"123), a nawet usiłował formułować projekt normalizacji relacji państwo-Kościół (jednym z warunków miało być zastąpienie Wyszyńskiego w Warszawie innym hierarchą i pozostawienie prymasowi jedynie archidiecezji gnieźnieńskiej) ${ }^{124}$. Jednakże, jedyne pozytywne rezultaty, jakie odnosił, wyrażały się $\mathrm{w}$ pacyfikowaniu tendencji opozycyjnych w $\mathrm{ChSS}^{125}$. Wkrótce jednak fakty miały zweryfikować pojawiające się opinie o Frankowskim jako o zręcznym graczu na "małym podwórku” 126 .

Autokratyczny styl zarządzania i brak sukcesów politycznych sprawiły, że w kwietniu 1968 r. prezes ChSS stał się ofiarą wewnętrznego przewrotu. Nie bez znaczenia było wspomniane już rosnące niezadowolenie partii z jego postawy i posądzenia o sprzyjanie „rewizjonistom”, autentyczna rezerwa wobec polityki PZPR w dobie wydarzeń marcowych, a także, jak się wydaje, spadek znaczenia swoistego protektora Frankowskiego, Kliszki ${ }^{127}$. Opozycja wewnętrzna w stowarzyszeniu mogła natomiast z sukcesem liczyć na pomoc gen. Moczara. Znamienne, że odwołany prezes, starając się odzyskać wpływy drogą zakulisową (m.in. proponując Piaseckiemu unię ChSS z Paxem) oraz emocjonalnymi demonstracjami, spotkał się tym razem ze zdecydowaną kontrakcją opozycji. Tak jak Frankowski w 1957 r. nie wpuszczał ludzi Micewskiego do lokalu redakcyjnego, tak też 11 lat później on sam został z siedziby ChSS wyproszony przez portiera. Próbując poniewczasie osiągnąć porozumienie z nowym prezesem, Filipowiczem ${ }^{128}$, spotykał się jedynie z lekceważeniem ${ }^{129}$.

123 J. Zabłocki, Dzienniki, s. 188.

124 AAN, UdsW, 129/12, Charakterystyka Jana Frankowskiego, k. 68; ibidem, AJF, 8, „Propozycje i postulaty Chrześcijańskiego Stowarzyszenia Społecznego”, 16 I 1967, b.pag.; ibidem, List Jana Frankowskiego do Edwarda Ochaba, ok. 1967, b.pag.

125 Zob. dokumenty dotyczące autokratycznych metod zarządzania Frankowskiego i procesów rozłamowych w ChSS: AIPN, 00231/231/2, „Notatka w sprawie sytuacji w ChSS i «Ars Christiana»”, 23 VII 1965, k. 82-86; ibidem, „Notatka służbowa z rozmowy z t.w. «Optymista»”, 4 XII 1965, k. 110; ibidem, „Doniesienie. Zebranie członków zwyczajnych ChSS w Warszawie 19 XII 1965” [źródło: „Mirosław”], 21 XII 1965, k. 115-117.

126 Zob. trafną charakterystykę lidera ChSS: AIPN, 00231/231/2, „Wyciąg z doniesienia t.w. «Ptak»", 5 IX 1966, k. 122-123.

127 O swoistości relacji Frankowskiego z Kliszką: J. Zabłocki, Dzienniki, s. 644.

128 UdsW charakteryzował Filipowicza jako pozbawionego własnych koncepcji politycznych. AAN, UdsW, 129/12, Charakterystyka Zygmunta Filipowicza, ok. 1965, k. 49.

129 AIPN, 00231/231/2, „Notatka na temat stosunków wewnętrznych w Chrześcijańskim Stowarzyszeniu Społecznym. Odpis notatki sporządzonej dla Urzędu do spraw Wyznań” [dot. usunięcia Frankowskiego], 30 IV 1968, k. 31-38; ibidem, „Informacja dot. Jana Frankowskiego" [nt. przebiegu zdarzeń w kierownictwie ChSS w marcu-kwietniu 1968 r.], 9 V 1968, k. 39-42; ibidem, „Notatka” [ze spotkania z t.w. „Mariusz”, nt. postawy Frankowskiego w marcu 1968 r.], 17 III 1968, k. 156-158; ibidem, „Notatka służbowa 
W 1969 r. uzyskał jeszcze mandat posła jako „bezpartyjny”, dzięki protekcji Kliszki i ku irytacji Filipowicza ${ }^{130}$, opublikował też kilka artykułów na łamach „Słowa Powszechnego”, nawiązując ponownie kontakt z Paxem ${ }^{131}$. Od 1972 r. znajdował się na politycznej emeryturze, aż do swej śmierci w 1976 r. Znamienne, że o wiele więcej miejsca poświęcono na łamach „Za i Przeciw” zmarłemu półtora roku później Łubieńskiemu niż twórcy tygodnika ${ }^{132}$.

Wydarzenia te oznaczały $\mathrm{w}$ istocie zepchnięcie ChSS na pozycje jeszcze bardziej wasalne wobec władzy ${ }^{133}$. O ile w 1957 r. rozłam w środowisku „Za i Przeciw” był skutkiem sporów ideowych, wobec których wtórne były ambicje poszczególnych stron, to w 1968 r. w stowarzyszeniu miał miejsce klasyczny „przewrót pałacowy”, warunkowany w pierwszej kolejności wieloaspektową niechęcią zarządu do prezesa ${ }^{134}$. Frankowski mógł czuć się jednak zwycięzcą w sensie ideowym - drogą, na którą pchnął środowisko w 1957 r., ChSS podążało także po jego odejściu. Wynikało to z taktyki komunistów, która, według szefa UdsW Aleksandra Skarżyńskiego głosiła, że „zawsze lepiej jest mieć trzy niż dwie grupy koncesjonowanych katolików"135.

Na początku października 1957 r. grupa „lewicy bezpartyjnej” pisała z nieukrywanym żalem do kierownictwa PZPR: „Trudno nam, choć przez

z rozmowy z t.w. «Optymista» w dniu 16 X 1968” [dot. prób kontrakcji Frankowskiego], 22 X 1968, k. 190. W czerwcu 1968 r. zawarto porozumienie, na mocy którego Frankowski mógł uczestniczyć w posiedzeniach zarządu głównego jedynie w sprawach związanych z jego obowiązkami redaktora „Hejnału Mariackiego”, AAN, ARR, 261, „Notatnik informacyjny dla członków Chrześcijańskiego Stowarzyszenia Społecznego”, 6 VIII 1968, b.pag.

130 AAN, UdSW, 129/12, List prezesa ChSS Zygmunta Filipowicza do Dyrektora UdsW Aleksandra Skarżyńskiego, 17 I 1972, k. 79-80.

131 J. Frankowski, Spostrzeżenia i uwagi. Kilka aktualnych refleksji, SP 1970, 78, s. 2; idem, Spostrzeżenia i uwagi. Dalszy krok naprzód $w$ doskonaleniu modelu, SP 1970, 96, s. 3.

132 Ś.p. Jan Frankowski, ZiP 1976, 8, s. 2; S. Żurowski, S.p. Konstanty Łubieński, ZiP 1977, 41, s. 2; W. Kętrzyński, Pamięci Konstantego Eubieńskiego, ZiP 1977, 43, s. 3.

133 Już w kwietniu 1968 r. ChSS zadeklarowało ponownie pełne poparcie dla polityki partii. Na początku lat siedemdziesiątych z zadowoleniem konstatowano w PZPR i UdsW aktywne wpisanie się ugrupowania w politykę władz. AAN, KC PZPR, XI/881, „Informacja o roli i perspektywach działalności Pax, «Znak» i ChSS”, I 1972, k. 11-12, 15; ibidem, 237/XIX-171, Janusz Makowski do kierownictwa PZPR w sprawie ChSS, VI 1971, k. 131-133; ibidem, UdsW, 74/75, „Informacja o działalności stowarzyszeń katolickich w 1974 r.", b.pag.; ibidem, ARR, 245, Referat polityczny wygłoszony przez Janusza Makowskiego na posiedzeniu Zarządu Głównego oraz na zjeździe ChSS, 6-7 IV 1968 r., b.pag.

134 AAN, UdsW, 129/12, List prezesa ChSS Zygmunta Filipowicza do Dyrektora UdSW Aleksandra Skarżyńskiego, 17 I 1972, k. 79-80.

135 A. Micewski, Katolicy w potrzasku, s. 50. 
chwilę założyć, że Kierownictwu Partii może zależeć na tym, by ludzie bezpartyjni, oddani szczerze sprawie lewicy, musieli uznać, że nie ma miejsca dla ich działalności w Ludowej Polsce po VIII Plenum, a taki wniosek musielibyśmy wyciągnąć z dotychczasowego przebiegu sprawy”136. Był to wniosek jak najbardziej słuszny, obrazujący fakt „końca Października" nie tylko w środowiskach katolików świeckich, ale i w życiu polityczno-intelektualnym PRL.

\section{Streszczenie}

Postawa Bolesława Piaseckiego, lidera Stowarzyszenia Pax, wobec przemian odwilżowych w PRL w połowie lat pięćdziesiątych spowodowała wzrastające niezadowolenie czołowych działaczy i ideologów organizacji. Jesienią 1956 r. podjęli oni próbę usunięcia Piaseckiego i zmiany linii politycznej organizacji, a gdy to się nie powiodło, dokonali „secesji”. Wobec braku szans na przejęcie wszystkich aktywów Paxu, Jan Frankowski, Konstanty Łubieński, Dominik Horodyński, Wojciech Kętrzyński i Andrzej Micewski powzięli decyzję o utworzeniu periodyku społeczno-politycznego „Za i Przeciw”, a na jego bazie ugrupowania katolików świeckich. Dyskusja na temat jego oblicza ideowego, toczona w zasadzie bez udziału Frankowskiego, doprowadziła do wykrystalizowania się koncepcji „bezpartyjnej lewicy demokratycznej", opartej na zasadach społecznego radykalizmu, geopolitycznego realizmu i deklaratywnego jedynie chrystianizmu. Z wizją taką nie zgadzał się lider środowiska, Frankowski, któremu udało się przekonać kierownictwo PZPR do tezy o „rewizjonizmie” ideologów „Za i Przeciw”. Dzięki temu zdołał na przełomie września i października usunąć ich z redakcji tygodnika oraz wkrótce potem powołać stojące na gruncie daleko idącej afirmacji rządów Gomułki Chrześcijańskie Stowarzyszenie Społeczne, programowo wyrzekające się snucia własnych koncepcji ideologicznych. Finałem tych wydarzeń było usunięcie Frankowskiego z kierownictwa ChSS w kwietniu 1968 r. z powodu zarzutów o autokratyczny styl zarządzania i brak jednoznacznego poparcia władz w dobie wydarzeń marcowych.

\section{At the Genesis of the Christian Social Association. The Emergence and Breakup of the First Editorial Team of the Za i Przeciw Weekly}

The attitude of Bolesław Piasecki, a leader of the PAX Association, towards the Thaw transformations in the Polish People's Republic in the mid-1950s led to a growing discontent of leading activists and ideologists of the Association.

136 AAN, KC PZPR, V-52, Memoriał byłych redaktorów „Za i Przeciw” do Sekretariatu KC PZPR, 2 X 1957, k. 230. 
In the autumn of 1956, they attempted to remove Piasecki from the leadership and change a political line of the organisation. After the failure, they made a secession. Having no chances to take over all the PAX's assets, Jan Frankowski, Konstanty Łubieński, Dominik Horodyński, Wojciech Kętrzyński, and Andrzej Micewski decided to establish a new socio-political periodical $\mathrm{Za}$ i Przeciw (For and Against), and to form on its basis a circle of secular Catholics. A discussion on its ideological shape, held in fact without Frankowski's participation, led to the crystallisation of a concept of "non-party democratic left", based on principles of social radicalism, geopolitical realism, and only a declarative Christianism. Frankowski did not agree with such a vision and managed to convince the leadership of the Polish United Workers' Party of "revisionism" of the Za i Przeciw ideologists. It made it possible for him to remove them from the weekly's editorial board in late September and early October, and soon afterwards to establish the Christian Social Association (Chrześcijańskie Stowarzyszenie Społeczne) based on the far-reaching affirmation of Gomulka's rule and the rejection of own ideological concepts. An episode of these events was Frankowski's dismissal from the leadership of the ChSA in April 1968 under a charge of autocratic style of management and due to the lack of explicit support of the state authorities during the 1968 March events.

Translated by Grażyna Waluga

\section{Bibliografia}

Andrusiewicz Andrzej, Stronnictwo Pracy 1937-1950. Ze studiów nad dziejami najnowszymi chadecji w Polsce, PWN, Warszawa 1988.

Bankowicz Bożena, Stowarzyszenie Pax. Między rzeczywistością socjalizmu realnego a utopia socjalizmu wieloświatopogladowego, w: Doktryny. Historia. Władza. Księga dedykowana profesorowi Wiesławowi Kozubowi-Cembroniewiczowi z okazji czterdziestolecia pracy naukowej, red. Anna Citkowska-Kimla, Małgorzata Kiwior-Filo, Bogdan Szlachta, Wydawnictwo UJ, Kraków 2009, s. 37-48.

Bankowicz Bożena, W labiryncie wieloświatopoglądowości. Stowarzyszenie Pax między realizmem a rzeczywistościa, w: Bożena Bankowicz, Antoni Dudek, Ze studiów nad dziejami Kościoła i katolicyzmu w PRL, PiT, Kraków 1996, s. 53-71.

Bankowicz Bożena, Neopozytywizm Znaku. Próba legalizmu motywowana realizmem, w: Bożena Bankowicz, Antoni Dudek, Ze studiów nad dziejami Kościoła i katolicyzmu w PRL, PiT, Kraków 1996, s. 37-52.

Błaszak Tomasz, Służba Bezpieczeństwa wobec Stowarzyszenia Pax i Chrześcijańskiego Stowarzyszenia Społecznego w województwie szczecińskim w latach 1952-1990, w: Sensus catholicus. Katolicy świeccy w Polsce Ludowej. Postawy - aktywność - myśl. Studia i szkice, red. red. Radosław Ptaszyński, Tomasz Sikorski, Wydawnictwo Adam Marszałek, Toruń 2014, s. 647-655.

Bocheński Aleksander, Dzieje głupoty w Polsce. Pamflety dziejopisarskie, Panteon, Warszawa 1947.

Bujak Waldemar, Historia Stronnictwa Pracy 1937-1946-1950, ODiSS, Warszawa 1988. 
Dudek Antoni, Pytel Grzegorz, Bolesław Piasecki. Próba biografii politycznej, Aneks, Londyn 1990.

Eska Juliusz, Kościół otwarty, Znak, Warszawa 1964.

Friszke Andrzej, Koło posłów „Znak” w Sejmie PRL 1957-1976, Wydawnictwo Sejmowe, Warszawa 2002.

Friszke Andrzej, Kościół a państwo realnego socjalizmu, „Więź” 1997, 3, s. 128-152.

Friszke Andrzej, Między wojna a więzieniem 1945-1953, Biblioteka „Więzi”, ISP PAN, Warszawa 2015.

Friszke Andrzej, Nadzieje i złudzenia. Środowiska katolików świeckich przed i po Październiku 1956, w: Sensus catholicus. Katolicy świeccy w Polsce Ludowej. Postawy aktywność - myśl. Studia i szkice, red. Radosław Ptaszyński, Tomasz Sikorski, Wydawnictwo Adam Marszałek, Toruń 2014, s. 74-114.

Friszke Andrzej, Opozycja polityczna w PRL 1945-1980, Aneks, Londyn 1994.

Friszke Andrzej, Dominika Horodyńskiego „uzupetnienia” historyczne, „Więź” 2001, 10, s. $120-135$.

Gucewicz Daniel, Dywersyjna rola Chrześcijańskiego Stowarzyszenia Społecznego w ruchu katolickim (na przykładzie Gdańska), w: Sensus catholicus. Katolicy świeccy w Polsce Ludowej. Postawy - aktywność - myśl. Studia i szkice, red. Radosław Ptaszyński, Tomasz Sikorski, Wydawnictwo Adam Marszałek, Toruń 2014, s. $627-646$.

Kaczorowski Andrzej W., Frankowski Jan Józef, w: Słownik biograficzny katolicyzmu społecznego w Polsce. A-J, red. Ryszard Bender et al., Towarzystwo Naukowe KUL, Lublin 1994, s. 134-135.

Kardela Piotr, W stużbie bezpieki i narodu. Wojciech Kętrzyński (1918-1983), „Rocznik Mazurski" 2015, 19, s. 151-180.

Kętrzyński Wojciech, Na przełomie 1944-1945, „Więź” 1967, 11-12, s. 160-171.

Kierys Arkadiusz, Polska Jasienicy. Biografia publicysty, Universitas, Kraków 2015.

Kimla Piotr, Realizm z fatszywej analogii historycznej wywiedziony. Przypadek Ksawerego Pruszyńskiego, „Politeja” 2013, 25, s. 177-188.

Kisielewski Stefan, Abecadło Kisiela, Interim, Warszawa 1990.

Kosicki Piotr H., Personalizm po polsku. Francuskie korzenie polskiej inteligencji katolickiej, IPN - KŚZpNP, Warszawa 2016.

Krajewski Kazimierz, Uderzeniowe Bataliony Kadrowe 1942-1944, Pax, Warszawa 1993.

Lisicka Halina, Pluralizm światopogladowy w koncepcjach Pax, ChSS, PZKS, Wydawnictwo Uniwersytetu Wrocławskiego, Wrocław 1991.

Łubieński Konstanty, Na starcie. Wspomnienia z lat 1948-1950, „Przegląd Socjologiczny" 1971, 24, s. 381-396.

Łubieński Konstanty, Kartki z wojny, ODISS, Warszawa 1976.

Micewski Andrzej, Katolicy w potrzasku. Wspomnienia z peryferii polityki, BGW, Warszawa 1993.

Micewski Andrzej, Współrządzić czy nie kłamać? Pax i Znak w Polsce 1945-1976, Oficyna NZS UJ „Jagiellonia”, Kraków 1981.

Micewski Andrzej, Dziennik idącego samotnie (czerwiec 1993 - wrzesień 1998), Projekt, Warszawa 1998.

Mozgol Ryszard, Ryzykowna gra. Jak Aleksander Bocheński przyczynił się do powstania „Dziś i Jutro”, „Biuletyn Instytutu Pamięci Narodowej” 2007, 4, s. 84-92. 
Piotrowski Mirosław, Służba idei czy serwilizm? Zygmunt Felczak i Feliks Widy-Wirski w najnowszych dziejach Polski, Redakcja Wydawnictw KUL, Lublin 1994.

Pót wieku polityki czyli Rzecz o obronie czynnej. Z Wiesławem Chrzanowskim rozmawiali Piotr Mirecki i Bogusław Kiernicki, Ad Astra, Warszawa 1997.

Ptaszyński Radosław, Stommizm. Biografia polityczna Stanisława Stommy, Znak, Kraków 2018.

Sikorski Tomasz, Fronda. Rozłam w Stowarzyszeniu Pax w 1955 roku. (Geneza - przebieg - konsekwencje), „Dzieje Najnowsze” 2018, nr 1, s. 201-227.

Sikorski Tomasz, Kulesza Marcin, Niezłomni w epoce fałszywych proroków. Środowisko „Tygodnika Warszawskiego” (1945-1948), von boroviecky, Warszawa 2013.

Stanosz Barbara, Wstęp, w: Empiryzm wspótczesny, red. Barbara Stanosz, Wydawnictwa UW, Warszawa 1991, s. 5-12.

Strzelecka Małgorzata, Między minimalizmem a maksymalizmem. Dylematy ideowe Stanisława Stommy i Janusza Zabłockiego, Wydawnictwo Naukowe UMK, Toruń 2015.

Zabłocki Janusz, Dzienniki 1956-1965, t. 1, IPN, Warszawa 2008.

Zabłocki Janusz, O jedność i transcendencję Kościoła. Przeciw wszelkim odmianom „immanencji politycznej", katolicyzmu, w: Janusz Zabłocki, Na polskim skrzyżowaniu dróg, ODISS, Warszawa 1972.

Zawieyski Jerzy, Dzienniki, t. 1: Wybór z lat 1955-1959, Ośrodek Karta - Dom Spotkań z Historią, Warszawa 2011.

Biog ram: Ariel Orzełek (ur. 1990), doktor nauk humanistycznych, adiunkt w Katedrze Metodologii i Badań nad XX-XXI w. UMCS. Zainteresowania naukowe: realizm polityczny w polskiej myśli politycznej i historycznej, środowiska katolików świeckich w Polsce powojennej, publicystyka polska doby najnowszej. Obecnie prowadzi badania nad postaciami i koncepcjami Jerzego Hagmajera, Jana Frankowskiego i Konstantego Łubieńskiego; kontakt: ariel.k.orzelek@gmail.com. 